\title{
Private Firm Valuation in the Technology Sector: Illuminating the Interaction Between Multiple Performance and Peer Pool Setting
}

\author{
Stefan Otto Grbenic \\ Faculty of Mechanical Engineering and Economic Sciences, Graz University of Technology, Graz, Austria \\ Email address: \\ stefan.grbenic@tugraz.at
}

To cite this article:

Stefan Otto Grbenic. Private Firm Valuation in the Technology Sector: Illuminating the Interaction Between Multiple Performance and Peer Pool Setting. International Journal of Economics, Finance and Management Sciences. Vol. 9, No. 2, 2021, pp. 77-96.

doi: 10.11648/j.ijefm.20210902.13

Received: October 1, 2020; Accepted: April 12, 2021; Published: May 8, 2021

\begin{abstract}
Prior research, investigating the absolute performance of multiples as well as the relative superiority of different types of multiples, yields contradictory results that might be attributed to varying peer pool settings. This paper emphasizes on the technology sector and extends existing research, in its entirety being limited to trading multiples on listed companies, to transaction multiples on private firms. Employing a set of 22,967 observations on private market transactions of technology firms collected from 2000 until 2018, I examine the systematic impact of peer pooling on (i) the relative superiority of cross-sectoral multiples, (ii) the absolute superiority of sectoral multiples and, (iii) the absolute superiority of cross-sectoral multiples being segmented by various country-specific high-tech indicators. The multiples employed capture both, enterprise value and equity value multiples. The performance of the multiples in the various peer pool settings is evaluated according to bias as well as accuracy, utilizing the standard holdout routine on the transactions. The results indicate that (i) contradictory results in prior research on multiple's bias may be strongly attributed to the varying peer pools employed, (ii) the enterprise value to total assets multiple clearly dominates across all peer pools on a cross-sectoral basis, indicating that contradictory results on multiple's accuracy may not be attributed to the varying peer pools employed and, (iii) the performance of sectoral multiples depends on the value driver employed, showing only a weak relationship with the peer pool setting. Therefore, valuation analysts are recommended to utilize larger peer pools when employing cross-sectoral multiples, to emphasize on the enterprise value to total assets multiple, to further break down the high-tech sector into sub-sectors and, to employ sectoral multiples or multiples segmented according to country-specific high-tech indicators alternately.
\end{abstract}

Keywords: Peer Pool, Peer Group, Multiple Performance, Transaction Multiples, Market Approach, Private Firms, Business Valuation, Technology Sector

\section{Introduction}

Over the years, numerous studies have been conducted, elaborating upon the absolute performance of multiples as well as on the relative superiority of a variety of multiple's definitions. These studies are subject to at least two limitations First, they are built upon varying samples that might be responsible for result's variations. Second, they are in its entirety limited to trading multiples generated from capital market data on listed companies. Since transactions on the market for corporate takeovers of private firms differ from stock deals on the public market on various characteristics, we cannot be sure if the results found for listed companies similarly hold for private firms. This study is - to my best knowledge - the first that discusses the impact of the peer pool (sample) employed on multiple's performance in the context of private firm valuation. Highlighted by the fact that the market for corporate takeovers of private firms is at least as important as the public market, utilizing the most appropriate peer pool in private firm valuation is a question of interest to valuation analysts, investors as well as the academic community.

This study contributes to existing research in threefold ways. First, it examines the systematic impact of peer pooling on (i) 
the relative superiority of cross-sectoral multiples, (ii) the absolute superiority of sectoral multiples and, (iii) the absolute superiority of cross-sectoral multiples being segmented by various country-specific high-tech indicators. Second, since transactions on the market for corporate takeovers differ from stock deals on the public market on various characteristics, it extends existing research (in its entirety being limited to listed companies) to transaction multiples emphasizing on private firms. Finally, since multiples are not stable over time, existing results are simply updated.

The results on bias indicate that the composition of the peer pool (i) impacts the least biased multiple, but generally the enterprise value multiples to outperform equity value multiples, (ii) impacts the level of superiority of sectoral multiples against the cross-sectoral multiple and, (iii) is not clearly related to the bias of multiples segmented according to country-specific high-tech indicators. The results on accuracy indicate that (i) cross sectoral multiples are unaffected by the peer pool setting (with the enterprise value to total assets multiple dominating), (ii) cross sectoral multiples estimates generally improve with an increase in peer pool size, (iii) sectoral multiples generally outperform the cross-sectoral multiple regardless of the peer pool setting and, (iv) segmenting multiples according to country-specific high-tech indicators offers no material improvement over sectoral multiples across all peer pools. All results are robust on both, according to the valuation error employed and the size of the peer group.

The remainder of this article is organized as follows: Section 2 discusses the literature on the performance of multiples. Section 3 defines the high-tech sector and reports descriptive statistics on sample data. Section 4 describes the research methodology. Section 5 reports the results on bias and accuracy of multiples across varying peer pool settings cross-sectoral, sector-related as well as according to country high-tech indicator segmentations. Section 6 reports the results on robustness tests. Finally, section 7 concludes.

\section{Literature Review}

Empirical evidence on the performance of multiples reveals contradictory results that may be attributed to varying peer pool settings (sampling). Evaluating the performance of enterprise value as opposed to equity value multiples, studies for the U. S. market generally conclude that enterprise value multiples outperform equity value multiples on both, accuracy and bias [1, 2]. In contrast, for emerging markets, studies conclude superiority of equity value multiples, explaining the inferiority of enterprise value multiples by the noise being incorporated when the book value of debt is used as a proxy for its market value [3, 4]. For European markets, the results are somewhat inconsistent, on the one hand concluding superiority of enterprise value multiples [5] and, on the other hand, finding equity value multiples do dominate $[6,7]$.

Examining the relative superiority of multiples according to the value driver employed, studies on European markets conclude earnings multiples to yield highest prediction accuracy [e. g. 6, 8, 9]. A similar result is found in an international setting [10]. In contrast, the results for the U. S. market yield somewhat contradictory results. While some studies similarly conclude earnings multiples to generate superior prediction accuracy [e. g. 11-16], other studies conclude asset multiples to generate more accurate and less biased estimates $[1,2,17]$. Furthermore, sales are found to be more value relevant than reported negative earnings in the valuation of high-tech loss firms [18].

On a sectoral basis, results of prior research are consistent in that different multiples are most accurate across industry sectors (for the U. S. market [13, 15, 19], for the European market [5, 20] and, for emerging markets [3, 4, 21]), but with varying relative superiorities that may be again attributed to peer pool sampling.

Finally, varying peer pool settings (the respective country itself, European Union member countries, OECD countries and, the U. S. market) are found to dominate when investigating optimal peer pools yielding minimum valuation errors of synthetic peer group multiples for European Union member countries [22].

\section{Sample Data}

I segment the high-tech sector into eight industry groupings based on five industry groupings widely used [23] as well as an extension adding two more industry groupings [24] and, by additionally adding an Automotive industry grouping. Since prior research reveals that the sectoral classification system employed impacts multiple's accuracy due to varying firms being assigned to industries [e. g. 25-31], and documents limitations as well as deficiencies of the widely used SIC codes to select and segment samples [25, 32, 33] due to its treatment of conglomerates [34], its emphasis on manufacturing operations [35] and, its product-based view not capturing vertical relationships among firms [36, 37], I employ the NACE Rev.2 industry classification.

Along with the findings on the optimal code combinations assigned to the various industries [25] as well as the succus on sampling employed in prior studies [e. g. 18, 23, 38-49], I convert SIC codes into NACE Rev. 2 codes and assign the respective code combinations to the eight predefined high-tech industry groupings as reported in table 1.

Table 1 reports the SIC code combinations recommended by literature and the converted NACE Rev.2 code combinations assigned to the eight predefined high-tech industry groupings.

The data is compiled from two sources. First, the information on transactions, pricing data and company data is obtained from ZEPHYR M\&A database, adding company data from ORBIS database to gain additional information on incomplete datasets to assure maximum data. Second, the data on country high-tech indicators is obtained from The World Bank (Science and Technology Indicators). 
Table 1. High-tech industry groupings and assigned industry classification code combinations.

\begin{tabular}{lll}
\hline High-Tech Industry & SIC code combination recommended & NACE Rev.2 code combination converted \\
\hline Computer Hardware and Electronics Manufacturing & 35,367 & $261,262,264,265,268,951$ \\
Communications & 366,48 & $263,60,61$ \\
Software Development & 73 & $582,62,631,742,802,951$ \\
Medical Technology & $28,38,87$ & $204,21,266,325,721$ \\
Electrical Manufacturing & 173,36 & $27,33,432$ \\
Internet \& IT-Services & $596,641,73,870,873,874$ & $479,581,732,822$ \\
Automotive & - & $29,309,452$ \\
Other High-Tech Industries & $261,272,28,29,34,35,37,381,387,491$, & $192,201,202,203,205,25,28,301,302,303$, \\
\hline
\end{tabular}

I started by identifying all private market transactions according to their deal type and extracted all acquisitions of minority as well as majority stakes (and simultaneously excluded all transactions of the deal types mergers, demergers, joint ventures, management buyouts and, institutional buyouts). The sample comprises all private market transactions observed in countries being categorized into the four cultural regions English origin, French origin, German origin and, Scandinavian origin [50]. Additionally, I introduced a fifth category capturing (post) communist countries. I collected all private market transactions, being confirmed or at least being assumed confirmed, occurring from 2000 until 2018, for which a complete dataset was available. Employing the method of static sampling ensures that similarities as well as differences across the various multiples and peer pool settings are not attributable to sampling. Although there is considerable debate upon the exclusion of negative value indications and/or negative value drivers in forming peer groups, I follow general practice (empirically concluding that the elimination of negative multiples improves valuation accuracy $[10,51,52])$ and employ only private market transactions providing both, positive value (pricing) indications and positive value driver metrics in order to ensure only positive multiples. The original sample population was 24,347 observations on private market transactions.

I limited the sample using only private market transactions indicating direct sales of common stock, as they can be considered as arm's length transactions representing fair market value. Therefore, I dropped all transactions of convertible preferred stock, stock options, or warrants, as they usually do not involve actual arm's-length negotiations that may cause a significant bias on the multiples. This reduced the sample by 562 observations. Furthermore, I dropped all transactions of firms with (i) sales below one million Euro, (ii) an EBITDA and/or an EBIT below 500,000 Euro and, (iii) total assets below two million Euro. This further reduced the sample by 818 observations. The final sample population is 22,967 observations on private market transactions (thus, representing 94.3 percent of the original sample), being distributed across countries of origin (indicating a concentration by a GINI coefficient of 0.776), peer pools (geographical/political as well as cultural regions) and, high-tech industry groupings as reported in table 2.

Table 2. Sample population by country, peer pool and, high-tech industry grouping.

Panel A: Sample population by country

\begin{tabular}{|c|c|c|c|}
\hline Country & count & Country & count \\
\hline Argentina & 1 & Kenya & 1 \\
\hline Australia & 1,639 & Luxembourg & 22 \\
\hline Austria & 49 & Malaysia & 238 \\
\hline Belgium & 276 & Malta & 4 \\
\hline Bosnia and Herzegovina & 13 & Montenegro & 8 \\
\hline Brazil & 9 & Netherlands & 1,405 \\
\hline Bulgaria & 7 & New Zealand & 172 \\
\hline Chile & 5 & Norway & 298 \\
\hline China & 375 & Pakistan & 6 \\
\hline Colombia & 3 & Philippines & 59 \\
\hline Croatia & 32 & Poland & 314 \\
\hline Cyprus & 3 & Portugal & 148 \\
\hline Czech Republic & 10 & Romania & 85 \\
\hline Denmark & 136 & Russia & 137 \\
\hline Estonia & 13 & Singapore & 50 \\
\hline Finland & 285 & Slovak Republic & 16 \\
\hline France & 1,632 & Slovenia & 33 \\
\hline Germany & 1,872 & South Africa & 10 \\
\hline Greece & 40 & South Korea & 4,666 \\
\hline Hong Kong & 1 & Spain & 825 \\
\hline Hungary & 84 & Sri Lanka & 11 \\
\hline Iceland & 2 & Sweden & 500 \\
\hline
\end{tabular}




\begin{tabular}{llll}
\hline Country & count & Country & count \\
\hline India & 579 & Switzerland & 383 \\
Indonesia & 2 & Taiwan & 237 \\
Ireland & 38 & Thailand & 74 \\
Israel & 6 & Turkey & 1 \\
Italy & 1,108 & Ukraine & 62 \\
Japan & 1,689 & United Kingdom & 1,522 \\
Jordan & 2 & United States & 1,545 \\
& & Total & 22,967 \\
\hline
\end{tabular}

Panel B: Sample population by peer pool and high-tech industry grouping

\begin{tabular}{|c|c|c|c|c|}
\hline \multirow{2}{*}{ Peer pool } & \multicolumn{4}{|c|}{ Geographical/Political Regions } \\
\hline & European Union & Europe & OECD & World \\
\hline Total (by countries) & 10,459 & 11,403 & 20,913 & 22,967 \\
\hline Computer Hardware and Electronics Manufacturing & 1,477 & 1,597 & 3,413 & 3,707 \\
\hline Communications & 1,285 & 1,466 & 2,413 & 2,677 \\
\hline Software Development & 2,844 & 3,053 & 5,860 & 6,228 \\
\hline Medical Technology & 987 & 1,127 & 2,501 & 2,703 \\
\hline Electrical Manufacturing & 1,268 & 1,338 & 2,203 & 2,422 \\
\hline Internet \& IT-Services & 842 & 950 & 1,572 & 1,689 \\
\hline Automotive & 764 & 774 & 1,436 & 1,589 \\
\hline Other High-Tech Industries & 3,418 & 3,817 & 7,066 & 7,915 \\
\hline Total (by industry groupings) & 12,885 & 14,122 & 26,464 & 28,930 \\
\hline
\end{tabular}

\begin{tabular}{llllll}
\hline \multirow{2}{*}{ Peer pool } & \multicolumn{2}{l}{ Cultural Regions } & & & \\
\cline { 2 - 6 } & English & French & German & Scandinavian & (Post) Communist \\
\hline Total (by countries) & 6,071 & 5,550 & 8,896 & 1,221 & 1,229 \\
Computer Hardware and Electronics Manufacturing & 664 & 799 & 2,085 & 97 & 62 \\
Communications & 814 & 806 & 724 & 132 & 201 \\
Software Development & 2,135 & 1,572 & 1,765 & 442 & 314 \\
Medical Technology & 661 & 377 & 1,375 & 144 & 146 \\
Electrical Manufacturing & 525 & 760 & 881 & 145 & 111 \\
Internet \& IT-Services & 583 & 385 & 510 & 95 & 116 \\
Automotive & 261 & 444 & 802 & 12 & 70 \\
Other High-Tech Industries & 1,835 & 1,776 & 3,446 & 380 & 478 \\
Total (by industry groupings) & 7,478 & 6,919 & 11,588 & 1,447 & 1,498 \\
\hline
\end{tabular}

Panel A reports the sample population by country. No observations were reported for Albania, Belarus, Ecuador, Kazakhstan, Kosovo, Latvia, Lithuania, Mexico, Moldova, Nigeria, Peru, Uruguay, Venezuela and, Zimbabwe. Panel B reports the sample population by peer pool (geographical/political as well as cultural regions) and high-tech industry grouping. Since firms may be engaged in more than one high-tech industry grouping, the total number of observations on the industry groupings exceeds the total number of observations by country.

\section{Research Methodology}

Despite the superiority of forward trading multiples $[1,5,7$, $8,10,11,13,15,53-56]$, since this study emphasizes on transaction multiples employing data from the market for corporate takeovers of private firms, I employ trailing multiples for at least three reasons: First, forecast value drivers are often simply not available for private firms as they are for public companies. Second, even if forecast value drivers are available, they often lack reliability or cannot be verified in a reliable manner, respectively. Third, value drivers employed in trailing multiples are less susceptible to manipulation, since the auditor's certificate ensures reliability.

I employ four enterprise value and one equity value multiple popular in valuation literature, namely the enterprise value to sales multiple, the enterprise value to EBITDA multiple, the enterprise value to EBIT multiple, the enterprise value to total assets multiple and, the equity value to EBT multiple. The sales multiple and the total assets multiple are denoted by $[7,57]$

$$
\lambda_{i}^{\delta_{i, j}}=\frac{E_{i}+T_{i}-I_{i}+D_{i}-C_{i}+L_{i}+P_{i}+A_{i}}{\delta_{i, j}}
$$

where $i$ is the index on firm transactions, $\delta_{i, j}$ is the value driver (with $j$ indicating operating sales and total assets), $\lambda_{i}^{\delta_{i, j}}$ is the enterprise value multiple on the corresponding value driver, $E_{i}$ is the market value of equity, $T_{i}$ is the market value of third party (minority) shares in subsidiaries, $I_{i}$ is the market value of investments in unconsolidated companies (associates and joint ventures), $D_{i}$ is the market value of straight debt (interest bearing liabilities), $C_{i}$ is the market value of cash and cash equivalents, $L_{i}$ is the market value of finance leases, $P_{i}$ is the market value of pension reserves and, 
$A_{i}$ is the market value of accounts payable.

The earnings multiples (EBITDA and EBIT) are denoted by

$$
\lambda_{i}^{\delta_{i, j}}=\frac{E_{i}+T_{i}-I_{i}+D_{i}-C_{i}+L_{i}\left(+P_{i}\right)}{\delta_{i}, j}
$$

where $i$ is the index on firm transactions, $\delta_{i, j}$ is the value driver (with $j$ indicating EBITDA and EBIT), $\lambda_{i}^{\delta_{i}, j}$ is the enterprise value multiple on the corresponding value driver, $E_{i}$ is the market value of equity, $T_{i}$ is the market value of third party (minority) shares in subsidiaries, $I_{i}$ is the market value of investments in unconsolidated companies (associates and joint ventures), $D_{i}$ is the market value of straight debt (interest bearing liabilities), $C_{i}$ is the market value of cash and cash equivalents, $L_{i}$ is the market value of finance leases and, $P_{i}$ is the market value of pension reserves (only being added if the interest on pensions is not part of the cost of goods sold).

The Equity Value to EBT multiple is denoted by

$$
\lambda_{i}^{\delta_{i, j}}=\frac{E_{i}}{\delta_{i, j}}
$$

where $i$ is the index on firm transactions, $\delta_{i, j}$ is the value driver (with $j$ indicating EBT), $\lambda_{i}^{\delta_{i, j}}$ is the equity value multiple on the corresponding value driver and, $E_{i}$ is the market value of equity.

I computed the datasets for each multiple, each peer pool as well as each high-tech sub-sample employing the standard holdout routine, once utilizing the target transaction as the transaction peers are searched for, and in all other cases serving as part of the peer group. Herewith, three fundamental methodological decisions are made concerning (i) the size of the peer group, (ii) the peer selection rule and, (iii) the method of aggregation employed. First, since a lower comparability of target firm and peers, a higher variance of the multiples and, a lower degree of marketability of the peers demand larger peer groups, I employ 10 peers according to sample characteristics. Research shows that the optimal size of the peer group is between 5 and 10 peers for most industry sectors, with a negative relationship between the size of the peer group and the number of available peers [58]. Some studies employ small peer groups consisting of four to five peers, respectively $[59,60]$, while in the oil and gas sector larger peer groups are found to generally yield superior synthetic multiples [61]. Second, I select peers estimating a Hausman-Taylor regression [62], allowing some of the regressors to be correlated with the individual effects [63]. The instrumental variables are selected according to both, variables employed in prior research $[5,6,9,14,64-68]$ and, simply, data availability on transactions, pricing and, company information The resulting set of 19 instrumental variables is assigned to four categories: (i) deal characteristics, (ii) transaction characteristics, (iii) market (for corporate takeovers) characteristics and, (iv) firm characteristics, with the latter being further categorized according to the three primary drivers of firm value (profitability, growth and, risk). For the definitions of the variables and related research see table 8 in the appendix. Third, I employ the harmonic mean and the median (corresponding to the aggregation method employed for the valuation errors) to aggregate the synthetic peer group multiples [6, 57].

Finally, I evaluate the performance of the multiples according to bias and accuracy. To evaluate bias, I employ the relative absolute valuation error, since it is both, exposed to a systematic upwards bias and avoids positive and negative deviations to net out (and hence, allows for a one-dimensional results figure) $[7,65,69,70]$. It is denoted by

$$
R A V E_{i}^{\delta_{i, j}}=\left|\frac{\widehat{\lambda_{l}^{\delta_{l, j}}}-\lambda_{i}^{\delta_{i, j}}}{\lambda_{i}^{\delta_{i, j}}}\right|
$$

where $i$ is the index on firm transactions, $\delta_{i, j}$ is the value driver (with $j$ indicating operating sales, EBITDA, EBIT, EBT and, total assets), $R A V E_{i}^{\delta_{i, j}}$ is the relative absolute valuation error on the corresponding value driver, $\widehat{\lambda}_{l}^{\delta_{l, j}}$ is the estimated enterprise value multiple on the corresponding value driver and, $\lambda_{i}^{\delta_{i, j}}$ is the observed enterprise value multiple on the corresponding value driver.

To evaluate accuracy, I employ the relative log-scaled absolute valuation error, since it avoids both, an upwards bias as well as the netting effect of positive and negative deviations, and, hence, considers solely the strength of the deviation $[1,6$, $52,53,56,57,71,72]$. It is denoted by

$$
R L A V E_{i}^{\delta_{i, j}}=\left|\ln \left(\frac{\overline{\lambda_{l}^{\delta, j}}}{\lambda_{i}^{\delta_{i, j}}}\right)\right|
$$

where $i$ is the index on firm transactions, $\delta_{i, j}$ is the value driver (with $j$ indicating operating sales, EBITDA, EBIT, EBT, and, total assets), $R L A V E_{i}^{\delta_{i, j}}$ is the relative log-scaled absolute valuation error on the corresponding value driver, $\widehat{\lambda_{l}} \widehat{\delta_{l, j}}$ is the estimated enterprise value multiple on the corresponding value driver and, $\lambda_{i}^{\delta_{i, j}}$ is the observed enterprise value multiple on the corresponding value driver.

I aggregate the relative absolute valuation errors employing the harmonic mean, since this maximizes the explanatory power on bias of the error measure itself $[12,13,15,66,73]$. In order to ensure unbiased estimates on accuracy, I aggregate the relative $\log$-scaled absolute valuation errors employing the median $[57,73]$.

\section{Results}

\subsection{Performance by Multiples and Peer Pool Settings}

In this section I examine the cross-sectoral performance of the multiples across various peer pool settings. Table 3 reports the results on the tests on bias and accuracy reported for the five multiples as well as aggregated, with the superior multiple in each peer pool being indicated in bold numbers. For the countries forming the various peer pools see table 9 in the appendix. 
Table 3. Performance (test on bias and accuracy) by multiples and peer pool settings.

Panel A: Test on Bias

\begin{tabular}{|c|c|c|c|c|c|c|}
\hline \multirow{2}{*}{ Multiples } & \multicolumn{6}{|c|}{ Geographical/Political Regions } \\
\hline & European Union & Europe & & OECD & & World \\
\hline Aggregated & 0.1240 & 0.1197 & & 0.0935 & & 0.0844 \\
\hline EPV/Sales & 0.1651 & 0.1236 & & 0.1466 & & 0.1278 \\
\hline EPV/EBITDA & 0.1149 & 0.1331 & & 0.0830 & & 0.0865 \\
\hline EPV/EBIT & 0.1502 & 0.0908 & & 0.0967 & & 0.0807 \\
\hline EPV/Total Assets & 0.0881 & 0.1100 & & 0.0713 & & 0.0582 \\
\hline EQV/EBT & 0.1326 & 0.1664 & & 0.0976 & & 0.0776 \\
\hline \multirow{2}{*}{ Multiples } & \multicolumn{6}{|l|}{ Cultural Regions } \\
\hline & English & French & German & & Scandinavian & (Post) Communist \\
\hline Aggregated & 0.0809 & 0.0684 & 0.0784 & & 0.0420 & 0.1270 \\
\hline EPV/Sales & 0.0910 & 0.2025 & 0.1473 & & 0.1775 & 0.0800 \\
\hline EPV/EBITDA & 0.0866 & 0.1457 & 0.0830 & & 0.0109 & 0.2046 \\
\hline EPV/EBIT & 0.0811 & 0.1357 & 0.0834 & & 0.1628 & 0.0897 \\
\hline EPV/Total Assets & 0.0782 & 0.0228 & 0.0531 & & 0.0941 & 0.1743 \\
\hline $\mathrm{EQV} / \mathrm{EBT}$ & 0.0707 & 0.1037 & 0.0711 & & 0.1959 & 0.1967 \\
\hline
\end{tabular}

Panel B: Test on Accuracy

\begin{tabular}{|c|c|c|c|c|}
\hline \multirow{2}{*}{ Multiples } & \multicolumn{4}{|c|}{ Geographical/Political Regions } \\
\hline & European Union & Europe & OECD & World \\
\hline Aggregated & 0.6461 & 0.6364 & 0.6193 & 0.6010 \\
\hline EPV/Sales & 0.8843 & 0.8838 & 0.7831 & 0.7584 \\
\hline EPV/EBITDA & 0.6599 & 0.6502 & 0.5594 & 0.5257 \\
\hline EPV/EBIT & 0.7826 & 0.7500 & 0.5738 & 0.5316 \\
\hline EPV/Total Assets & 0.4651 & 0.4633 & 0.4029 & 0.3789 \\
\hline EQV/EBT & 0.5662 & 0.5622 & 0.5186 & 0.5004 \\
\hline
\end{tabular}

\begin{tabular}{lllll}
\hline \multirow{2}{*}{ Multiples } & Cultural Regions & & & \\
\cline { 2 - 5 } & English & French & German & Scandinavian \\
\hline Aggregated & 0.4039 & 0.6076 & 0.4555 & 0.6512 \\
EPV/Sales & 0.5705 & 0.8766 & 0.5578 & 0.8362 \\
EPV/EBITDA & 0.3633 & 0.6115 & 0.4858 & 0.6110 \\
EPV/EBIT & 0.3857 & 0.7496 & 0.5250 & 0.6441 \\
EPV/Total Assets & 0.3579 & 0.4273 & 0.3232 & 0.4225 \\
EQV/EBT & 0.4382 & 0.5447 & 0.4376 & 0.7250 \\
\hline
\end{tabular}

EPV indicates enterprise value, EQV indicates equity value. Panel A reports the results on bias employing the relative absolute valuation error aggregated by the harmonic mean. Panel B reports the results on accuracy employing the relative log-scaled absolute valuation error aggregated by the median.

The results for the test on bias indicate that the least biased multiple varies across peer pool settings. Furthermore, the results indicate enterprise value multiples to outperform the equity value multiple (except for the peer pool capturing countries of English origin) and the multiples to perform differently across peer pools. The results for the test on accuracy indicate the enterprise value to total assets multiple to dominate across all peer pool settings generating most accurate multiple estimates, being followed by the equity value multiple (as indicated for the geographical/political peer pools). Furthermore, the results indicate the multiples estimates to improve with an increase in peer pool size (as indicated by the geographical/political peer pools). Therefore, the results allow for the general conclusion that (i) contradictory results on multiple's bias concluded in prior research may be attributed to the varying peer pools employed, (ii) contradictory results on multiple's accuracy may not be attributed to the varying peer pools employed (but to other sample characteristics), (iii) valuation analysts are advised to employ larger peer pools and, (iv) valuation analysts may emphasize the enterprise value to total assets multiple valuing high-tech firms (although intangible assets not captured by the multiple play an important role for high-tech firms).

\subsection{Performance by High-Tech Sector Segmentation and Peer Pool Settings}

In this section I examine the aggregated performance of sectoral multiples across various peer pool settings. Table 4 reports the results on the tests on bias and accuracy for all five multiples aggregated as well as for the eight predefined high-tech industries separated, with the sectoral multiples outperforming the cross-sectoral multiple being indicated in bold numbers. For the countries forming the various peer pools see table 9 in the appendix. 
Table 4. Performance (test on bias and accuracy) by sector segmentation and peer pool settings.

Panel A: Test on Bias

\begin{tabular}{|c|c|c|c|c|c|}
\hline \multirow{2}{*}{ High-Tech Industries } & \multicolumn{5}{|c|}{ Geographical/Political Regions } \\
\hline & \multicolumn{2}{|c|}{ European Union } & Europe & OECD & World \\
\hline Cross-Sectoral & 0.1240 & & & 0.0935 & 0.0844 \\
\hline Computer Hardware and Electronics Manufacturing & 0.1039 & & & 0.0415 & 0.0742 \\
\hline Communications & 0.1003 & & & 0.1134 & 0.0836 \\
\hline Software Development & 0.1270 & & & 0.1034 & 0.0879 \\
\hline Medical Technology & 0.0802 & & & 0.0519 & 0.0706 \\
\hline Electrical Manufacturing & 0.1710 & & & 0.1324 & 0.0701 \\
\hline Internet \& IT-Services & 0.1225 & & & 0.0671 & 0.0043 \\
\hline Automotive & 0.0653 & & & 0.0079 & 0.0900 \\
\hline Other High-Tech Industries & 0.1189 & & & 0.0897 & 0.0390 \\
\hline \multirow{2}{*}{ High-Tech Industries } & \multicolumn{5}{|l|}{ Cultural Regions } \\
\hline & English $\quad$ I & French & German & Scandinavian & (Post) Communist \\
\hline Cross-Sectoral & 0.0809 & 0.0684 & 0.0784 & 0.0420 & 0.1270 \\
\hline Computer Hardware and Electronics Manufacturing & 0.0778 & 0.0639 & 0.0953 & 0.2839 & 0.2108 \\
\hline Communications & 0.0773 & 0.1175 & 0.1026 & 0.0759 & 0.0533 \\
\hline Software Development & 0.0739 & 0.1179 & 0.0965 & 0.2628 & 0.1373 \\
\hline Medical Technology & 0.1361 & 0.0440 & 0.0894 & 0.1115 & 0.1421 \\
\hline Electrical Manufacturing & 0.0430 & 0.0932 & 0.0714 & 0.1802 & 0.2134 \\
\hline Internet \& IT-Services & 0.0951 & 0.1735 & 0.1020 & 0.1997 & 0.0043 \\
\hline Automotive & 0.1077 & 0.0224 & 0.0208 & 0.4019 & 0.0168 \\
\hline Other High-Tech Industries & 0.1034 & 0.1131 & 0.0655 & 0.1235 & 0.1734 \\
\hline
\end{tabular}

Panel B: Test on Accuracy

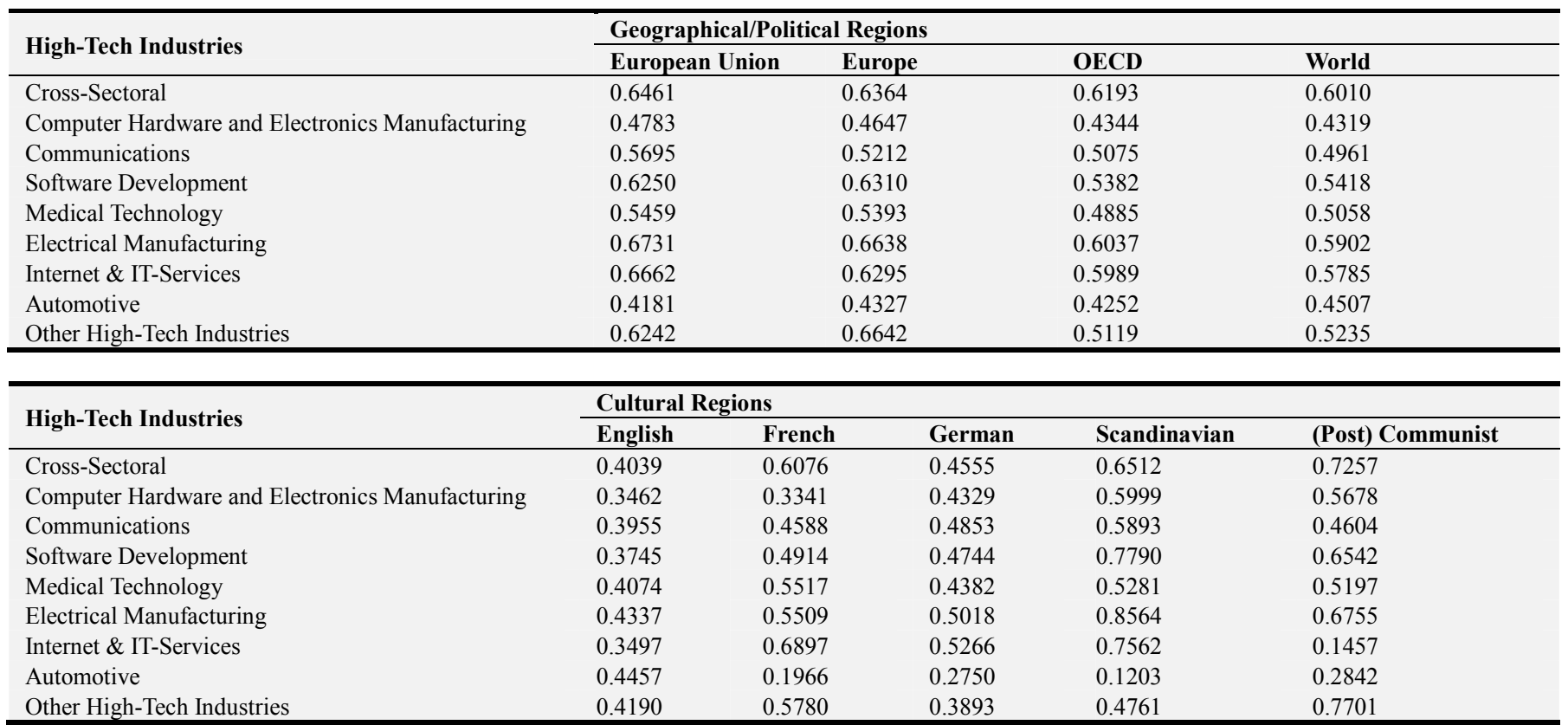

Panel A reports the results on bias employing the relative absolute valuation error aggregated by the harmonic mean. Panel B reports the results on accuracy employing the relative log-scaled absolute valuation aggregated by the median.

The results for the test on bias indicate sectoral multiples to outperform the cross-sectoral multiple, but at varying levels across peer pools. For peer pools formed by geographical/political characteristics, the sectoral multiples in the sectors Computer Hardware and Electronics, Medical Technology and, Other High-Tech Industries are less biased across all peer pools, while the Software Development multiple does not improve in any peer pool. Instead, for peer pools formed by cultural characteristics, none of the sectoral multiples outperforms the cross-sectoral multiple across all peer pools, with no sectoral multiple outperforming the cross-sectoral multiple in any sector for Scandinavian countries. This may be attributed to the small sample size for this cultural region. The results for the test on accuracy indicate sectoral multiples to outperform the cross-sectoral multiple in the geographical/political peer pools in most sectors. A somewhat similar, but weaker, conclusion can be drawn for the cultural peer pools. Therefore, the results allow for the general 
conclusion that (i) contradictory results concluded in prior research on multiple's bias may strongly be attributed to the peer pool employed, (ii) the accuracy of sectoral multiples shows only a weak relationship with the peer pool employed, and, thus, the somewhat contradictory results found in previous research may be attributed to the value driver employed, (iii) since the sectoral multiples do not show a clear improvement with an increase in the size of the peer pool, valuation analysts may not be forced to employ large-sized peer pools and, (iv) valuation analysts are advised to further break down the high-tech sector.

\subsection{Performance by Country High-Tech Indicator Segmentation and Peer Pool Settings}

In this section I examine whether a segmentation according to country-specific high-tech indicators improves the performance of cross-sectoral multiples across the various peer pool settings and, thus, is a viable alternative to the high-tech industry segmentation. Table 5 reports the results on the tests on bias and accuracy for all five multiples aggregated for various segmentations according to country-specific high-tech indicators: (i) Research \& development expenditure in percent of the gross domestic product (R\&D\% GDP), technology exports in percent of the gross domestic product (TE\%GDP) and, technology exports in percent of total manufactured exports (TE\%TME), with the countries sorted in descending order and grouped into quarters (according to the number of observations on multiples) from the countries with the highest percentage (quarter 1) to the lowest percentage (quarter 4). (ii) Labor force needed per patent application (LFPA), with the countries sorted in ascending order and grouped into quarters (according to the number of observations on multiples) from the countries with the lowest labor force (quarter 1) to the highest labor force (quarter 4) needed. (iii) High-tech index being computed as the weighted mean of the previous four indicators, grouped into quarters (according to the number of observations on multiples) from countries with the highest index (quarter 1) to the lowest index (quarter 4) as well as grouped into four minimum range clusters, again from countries with the highest index (cluster 1) to the lowest index (cluster 4). For the countries forming the various peer pools (being limited to the geographical/political peer pools due to sampling) as well as the classification of countries according to the country high-tech indicators and the quarters/clusters, respectively, see table 9 in the appendix. The quarters/clusters outperforming the aggregate performance are indicated in bold numbers.

Table 5. Performance (test on bias and accuracy) by country high-tech indicator segmentation and peer pool settings.

Panel A: Test on Bias

\begin{tabular}{|c|c|c|c|c|}
\hline Country High-Tech Indicator & European Union & Europe & OECD & World \\
\hline Aggregated/Cross-Sectoral & 0.1240 & 0.1197 & 0.0935 & 0.0844 \\
\hline \multicolumn{5}{|l|}{ R\&D\%GDP } \\
\hline Quarter 1 & 0.1149 & 0.1629 & 0.1188 & 0.0698 \\
\hline Quarter 2 & 0.0897 & 0.0918 & 0.0408 & 0.0899 \\
\hline Quarter 3 & 0.0966 & 0.0864 & 0.0847 & 0.0992 \\
\hline Quarter 4 & 0.1541 & 0.1701 & 0.0698 & 0.1272 \\
\hline Quarter 1 & 0.1048 & 0.0563 & 0.0698 & 0.0712 \\
\hline Quarter 2 & 0.1610 & 0.1002 & 0.0676 & 0.0752 \\
\hline Quarter 3 & 0.1235 & 0.0998 & 0.1263 & 0.0773 \\
\hline Quarter 4 & 0.1804 & 0.1497 & 0.1197 & 0.1197 \\
\hline \multicolumn{5}{|l|}{ TE\%GDP } \\
\hline Quarter 1 & 0.0737 & 0.0206 & 0.0980 & 0.0970 \\
\hline Quarter 3 & 0.1343 & 0.1343 & 0.0882 & 0.1273 \\
\hline Quarter 4 & 0.1339 & 0.1674 & 0.0939 & 0.0490 \\
\hline \multicolumn{5}{|l|}{ TE\%TME } \\
\hline Quarter 1 & 0.1028 & 0.0973 & 0.0301 & 0.0001 \\
\hline Quarter 2 & 0.0965 & 0.0968 & 0.0472 & 0.0691 \\
\hline Quarter 3 & 0.1055 & 0.1161 & 0.1149 & 0.1330 \\
\hline Quarter 4 & 0.1894 & 0.1437 & 0.1288 & 0.0699 \\
\hline \multicolumn{5}{|l|}{ High-Tech Index (quarters) } \\
\hline Quarter 1 & 0.1592 & 0.1315 & 0.0698 & 0.0162 \\
\hline Quarter 2 & 0.0979 & 0.0979 & 0.1050 & 0.1178 \\
\hline Quarter 3 & 0.0132 & 0.1527 & 0.1172 & 0.0889 \\
\hline Quarter 4 & 0.1673 & 0.1486 & 0.1447 & 0.1284 \\
\hline \multicolumn{5}{|l|}{ High-Tech Index (clustered) } \\
\hline Cluster 1 & 0.1584 & 0.0995 & 0.0712 & 0.0690 \\
\hline Cluster 4 & 0.1030 & 0.0352 & 0.1525 & 0.0777 \\
\hline
\end{tabular}


Panel B: Test on Accuracy

\begin{tabular}{|c|c|c|c|c|}
\hline Country High-Tech Indicator & European Union & Europe & OECD & World \\
\hline \multicolumn{5}{|l|}{$\mathrm{R} \& \mathrm{D} \% \mathrm{GDP}$} \\
\hline Quarter 1 & 0.6763 & 0.7021 & 0.6183 & 0.4577 \\
\hline Quarter 2 & 0.5177 & 0.4710 & 0.4428 & 0.5275 \\
\hline Quarter 3 & 0.4511 & 0.5227 & 0.5266 & 0.4522 \\
\hline Quarter 4 & 0.6704 & 0.6488 & 0.4577 & 0.6204 \\
\hline \multicolumn{5}{|l|}{ LFPA } \\
\hline Quarter 1 & 0.5998 & 0.5931 & 0.3765 & 0.3842 \\
\hline Quarter 2 & 0.6456 & 0.6471 & 0.3766 & 0.4778 \\
\hline Quarter 3 & 0.4774 & 0.4725 & 0.6274 & 0.6244 \\
\hline Quarter 4 & 0.7194 & 0.7402 & 0.6114 & 0.5999 \\
\hline \multicolumn{5}{|l|}{ TE\%GDP } \\
\hline Quarter 1 & 0.5854 & 0.4830 & 0.4449 & 0.4403 \\
\hline Quarter 2 & 0.6428 & 0.6109 & 0.5784 & 0.5952 \\
\hline Quarter 3 & 0.5444 & 0.5444 & 0.5559 & 0.5868 \\
\hline Quarter 4 & 0.6813 & 0.6761 & 0.5229 & 0.5082 \\
\hline \multicolumn{5}{|l|}{ TE\%TME } \\
\hline Quarter 1 & 0.4805 & 0.4781 & 0.3838 & 0.4020 \\
\hline Quarter 2 & 0.5888 & 0.5927 & 0.4397 & 0.4478 \\
\hline Quarter 3 & 0.5979 & 0.6057 & 0.6328 & 0.6370 \\
\hline Quarter 4 & 0.6839 & 0.6744 & 0.5925 & 0.5764 \\
\hline \multicolumn{5}{|l|}{ High-Tech Index (quarters) } \\
\hline Quarter 1 & 0.6769 & 0.6534 & 0.3764 & 0.3842 \\
\hline Quarter 2 & 0.4971 & 0.4971 & 0.4929 & 0.5549 \\
\hline Quarter 3 & 0.5268 & 0.5569 & 0.6132 & 0.4724 \\
\hline Quarter 4 & 0.6822 & 0.7035 & 0.5771 & 0.6230 \\
\hline \multicolumn{5}{|l|}{ High-Tech Index (clustered) } \\
\hline Cluster 1 & 0.6408 & 0.5906 & 0.3842 & 0.3744 \\
\hline Cluster 2 & 0.5723 & 0.5990 & 0.5522 & 0.4217 \\
\hline Cluster 3 & 0.6729 & 0.5878 & 0.4853 & 0.5642 \\
\hline Cluster 4 & 0.6853 & 0.6885 & 0.6848 & 0.6629 \\
\hline
\end{tabular}

Panel A reports the results on bias employing the relative absolute valuation error aggregated by the harmonic mean. Panel B reports the results on accuracy employing the log-scaled absolute valuation error aggregated by the median.

The results for the test on bias (as reported in panel A) indicate that the multiples segmented into quarters outperform the aggregated multiple unsystematically for the various country high-tech indicators. Furthermore, the results indicate no systematic relationship between the magnitude of bias and peer pools. Finally, the country high-tech indicator segmented multiples show no material improvement over the sectoral multiples irrespective of the peer pool setting employed. The results for the test on accuracy (as reported in panel B) similarly indicate the country high-tech indicator segmented multiples to unsystematically outperform the aggregated multiple, but with a weak tendency to improve for the larger peer pools. Furthermore, the multiples show no material improvement over sectoral multiples across all peer pools. Therefore, the results allow for the general conclusion that (i) valuation analysts may not gain improvement when sub-segmenting the peer pools by country high-tech indicators on both, bias and accuracy, (ii) the size of the peer pool has no material impact on the performance of the country high-tech indicator segmented multiples and, (iii) valuation analysts may employ sectoral multiples or country high-tech indicator segmented multiples alternately.

\section{Robustness Tests}

In this section, I test the results on accuracy on both, whether they are robust to the valuation error and the size of the peer group employed. First, I repeat the computations in order to evaluate whether the previous results are sensitive to the valuation error employed. Therefore, I replace the relative log-scaled absolute valuation error by the relative squared valuation error, since the latter does not only indicate the strength of the deviation between the estimated and the observed multiple, but is sensitive to extreme values yielding larger errors in case of severe over- or underestimation [11]. This incorporates valuable information on the distribution and homogeneity. The relative squared valuation error is denoted by

$$
\operatorname{RSVE}_{i}^{\delta_{i, j}}=\left(\frac{\widehat{\lambda_{l}^{\delta_{l, j}}}-\lambda_{i}^{\delta_{i, j}}}{\lambda_{i}^{\delta_{i, j}}}\right)^{2}
$$

where $i$ is the index on firm transactions, $\delta_{i, j}$ is the value driver (with $j$ indicating operating sales, EBITDA, EBIT, EBT and, total assets), $R S V E_{i}^{\delta_{i, j}}$ is the relative squared valuation error on the corresponding value driver, $\widehat{\lambda_{l}} \widehat{\delta_{l, j}}$ is the estimated enterprise value multiple on the corresponding value driver and, $\lambda_{i}^{\delta_{i, j}}$ is the observed enterprise value multiple on the corresponding value driver. 
As with the relative log-scaled absolute valuation error, in order to ensure unbiased estimates on accuracy, I aggregate the results of the relative squared valuation error employing the median.

Table 6 reports the results on the test on accuracy by multiples, high-tech sector segmentation and, country high-tech indicator segmentation, employing the relative squared valuation error. The superior multiple (panel A), the sectoral multiples outperforming the cross-sectoral multiple (panel B) and, the quarters/clusters for the country high-tech indicator segmented multiples outperforming the aggregated multiples (panel $\mathrm{C}$ ) are indicated in bold numbers. For the countries forming the various peer pools see table 9 in the appendix.

Table 6. Performance (test on accuracy) by multiples, sector segmentation, country high-tech indicator segmentation and, peer pool settings.

Panel A: Performance (test on accuracy) by multiples and peer pool settings

\begin{tabular}{|c|c|c|c|c|c|c|}
\hline \multirow{2}{*}{ Multiples } & \multicolumn{6}{|c|}{ Geographical/Political Regions } \\
\hline & European Union & Europe & & OECD & & \\
\hline Aggregated & 0.3412 & 0.3337 & & 0.2556 & & \\
\hline EPV/Sales & 0.5359 & 0.5335 & & 0.4411 & & \\
\hline EPV/EBITDA & 0.3637 & 0.3492 & & 0.2770 & & \\
\hline EPV/EBIT & 0.4674 & 0.4421 & & 0.2889 & & \\
\hline EPV/Total Assets & 0.1857 & 0.1826 & & 0.1450 & & \\
\hline EQV/EBT & 0.2710 & 0.2663 & & 0.2355 & & \\
\hline \multirow{2}{*}{ Multiples } & \multicolumn{6}{|l|}{ Cultural Regions } \\
\hline & English & French & German & & Scandinavian & (Post) Communist \\
\hline Aggregated & 0.1470 & 0.5334 & 0.1863 & & 0.3418 & 0.4017 \\
\hline EPV/Sales & 0.2167 & 0.5568 & 0.2584 & & 0.5038 & 0.4823 \\
\hline EPV/EBITDA & 0.1205 & 0.3284 & 0.2143 & & 0.3205 & 0.3662 \\
\hline EPV/EBIT & 0.1379 & 0.4295 & 0.2450 & & 0.3469 & 0.3930 \\
\hline EPV/Total Assets & 0.1168 & 0.1612 & 0.1003 & & 0.1683 & 0.3305 \\
\hline EQV/EBT & 0.1678 & 0.2546 & 0.1726 & & 0.4567 & 0.4439 \\
\hline
\end{tabular}

Panel B: Performance (test on accuracy) by sector segmentation and peer pool settings

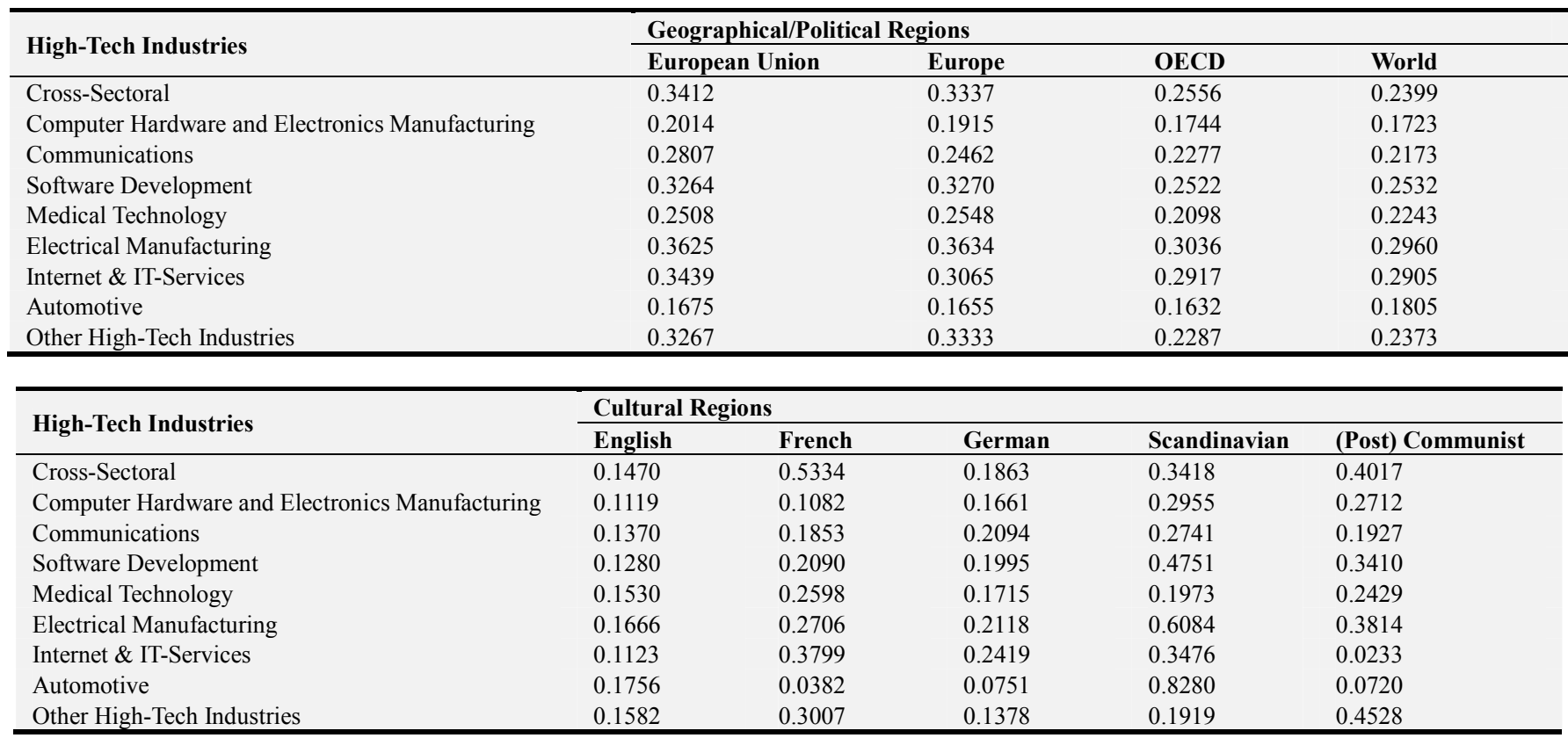

Panel C: Performance (test on accuracy) by country high-tech indicator segmentation and peer pool settings

\begin{tabular}{llll}
\hline Country High-Tech Indicator & European Union & Europe & OECD \\
\hline $\begin{array}{l}\text { Aggregated/Cross-Sectoral } \\
\text { R\&D\%GDP }\end{array}$ & 0.3412 & 0.3337 & 0.2556 \\
Quarter 1 & & & \\
Quarter 2 & 0.3476 & 0.3899 & 0.3154 \\
Quarter 3 & 0.2357 & 0.1913 & 0.1814 \\
Quarter 4 & 0.1746 & 0.2331 & 0.2373 \\
LFPA & 0.3591 & 0.3408 & 0.1836 \\
Quarter 1 & & & 0.1836 \\
Quarter 2 & 0.2896 & 0.2934 & 0.1869 \\
Quarter 3 & 0.3388 & 0.3408 & 0.3222 \\
Quarter 4 & 0.1941 & 0.1942 & 0.1300 \\
\hline
\end{tabular}




\begin{tabular}{|c|c|c|c|c|}
\hline Country High-Tech Indicator & European Union & Europe & OECD & World \\
\hline \multicolumn{5}{|l|}{ TE\%GDP } \\
\hline Quarter 1 & 0.2925 & 0.2026 & 0.1785 & 0.1719 \\
\hline Quarter 2 & 0.3263 & 0.2988 & 0.2884 & 0.2929 \\
\hline Quarter 3 & 0.2465 & 0.2465 & 0.2623 & 0.2811 \\
\hline Quarter 4 & 0.3679 & 0.3625 & 0.2390 & 0.2263 \\
\hline \multicolumn{5}{|l|}{ TE\%TME } \\
\hline Quarter 1 & 0.2056 & 0.2093 & 0.1314 & 0.1469 \\
\hline Quarter 2 & 0.2953 & 0.2844 & 0.1751 & 0.1772 \\
\hline Quarter 3 & 0.2897 & 0.2867 & 0.3312 & 0.3323 \\
\hline Quarter 4 & 0.3695 & 0.3635 & 0.2945 & 0.2877 \\
\hline \multicolumn{5}{|l|}{ High-Tech Index (quarters) } \\
\hline Quarter 1 & 0.3668 & 0.3352 & 0.1299 & 0.1347 \\
\hline Quarter 2 & 0.2206 & 0.2206 & 0.2116 & 0.2650 \\
\hline Quarter 3 & 0.2455 & 0.2615 & 0.3031 & 0.2030 \\
\hline Quarter 4 & 0.3738 & 0.3930 & 0.2887 & 0.3236 \\
\hline \multicolumn{5}{|l|}{ High-Tech Index (clustered) } \\
\hline Cluster 1 & 0.3218 & 0.2983 & 0.1352 & 0.1268 \\
\hline Cluster 2 & 0.2815 & 0.3001 & 0.2587 & 0.1581 \\
\hline Cluster 3 & 0.3561 & 0.2807 & 0.2079 & 0.2718 \\
\hline Cluster 4 & 0.3765 & 0.3588 & 0.3688 & 0.3494 \\
\hline
\end{tabular}

$\mathrm{EPV}$ indicates enterprise value, $\mathrm{EQV}$ indicates equity value. Panel A reports the results on the performance (accuracy) by multiples. Panel B reports the results on the performance (accuracy) by high-tech sector segmentation. Panel C reports the results on the performance (accuracy) by country high-tech indicator segmentation. For all panels, both, the synthetic peer group multiple and the relative squared valuation error, are aggregated employing the median.

Second, in order to evaluate whether the previous results are sensitive to the size of the peer groups employed, I repeat the computations (based on the relative log-scaled absolute valuation error) employing smaller peer groups capturing only five peers. Table 7 reports the results on the test on accuracy by multiples, high-tech sector segmentation and, country high-tech indicator segmentation. The superior multiple (panel A), the sectoral multiples outperforming the cross-sectoral multiple (panel B) and, the quarters/clusters for the country-specific high-tech indicators outperforming the aggregated multiples (panel $\mathrm{C}$ ) are indicated in bold numbers. For the countries forming the various peer pools see table 9 in the appendix.

Table 7. Performance (test on accuracy) by multiples, sector segmentation, country high-tech indicator segmentation and, peer pool settings.

Panel A: Performance (test on accuracy) by multiples and peer pool settings

\begin{tabular}{|c|c|c|c|c|c|c|}
\hline \multirow{2}{*}{ Multiples } & \multicolumn{6}{|c|}{ Geographical/Political Regions } \\
\hline & European Union & Europe & & OECD & & \\
\hline Aggregated & 0.6901 & 0.6752 & & 0.6590 & & \\
\hline EPV/Sales & 0.9366 & 0.9412 & & 0.8276 & & \\
\hline EPV/EBITDA & 0.7093 & 0.6907 & & 0.5723 & & \\
\hline EPV/EBIT & 0.8264 & 0.7867 & & 0.6119 & & \\
\hline EPV/Total Assets & 0.4951 & 0.4967 & & 0.4392 & & \\
\hline EQV/EBT & 0.6185 & 0.6022 & & 0.5578 & & \\
\hline \multirow{2}{*}{ Multiples } & \multicolumn{6}{|l|}{ Cultural Regions } \\
\hline & English & French & German & & Scandinavian & (Post) Communist \\
\hline Aggregated & 0.4330 & 0.6514 & 0.4870 & & 0.7038 & 0.7704 \\
\hline EPV/Sales & 0.5396 & 0.9482 & 0.5921 & & 0.9102 & 0.9375 \\
\hline EPV/EBITDA & 0.3853 & 0.6536 & 0.5252 & & 0.6578 & 0.7265 \\
\hline EPV/EBIT & 0.4140 & 0.7969 & 0.5596 & & 0.7160 & 0.7120 \\
\hline EPV/Total Assets & 0.3769 & 0.4419 & 0.3565 & & 0.4515 & 0.6593 \\
\hline
\end{tabular}

Panel B: Performance (test on accuracy) by sector segmentation and peer pool settings

\begin{tabular}{llll}
\hline \multirow{2}{*}{ High-Tech Industries } & \multicolumn{2}{l}{ Geographical/Political Regions } \\
\cline { 2 - 4 } & European Union & Europe & OECD \\
\hline Cross-Sectoral & 0.6901 & 0.6752 & 0.6590 \\
Computer Hardware and Electronics Manufacturing & 0.5056 & 0.4974 & 0.6451 \\
Communications & 0.6031 & 0.5812 & 0.4605 \\
Software Development & 0.6719 & 0.6825 & 0.5508 \\
Medical Technology & 0.5972 & 0.5849 & 0.5804 \\
Electrical Manufacturing & 0.7225 & 0.7118 & 0.5174 \\
Internet \& IT-Services & 0.7244 & 0.6638 & 0.6493 \\
\end{tabular}




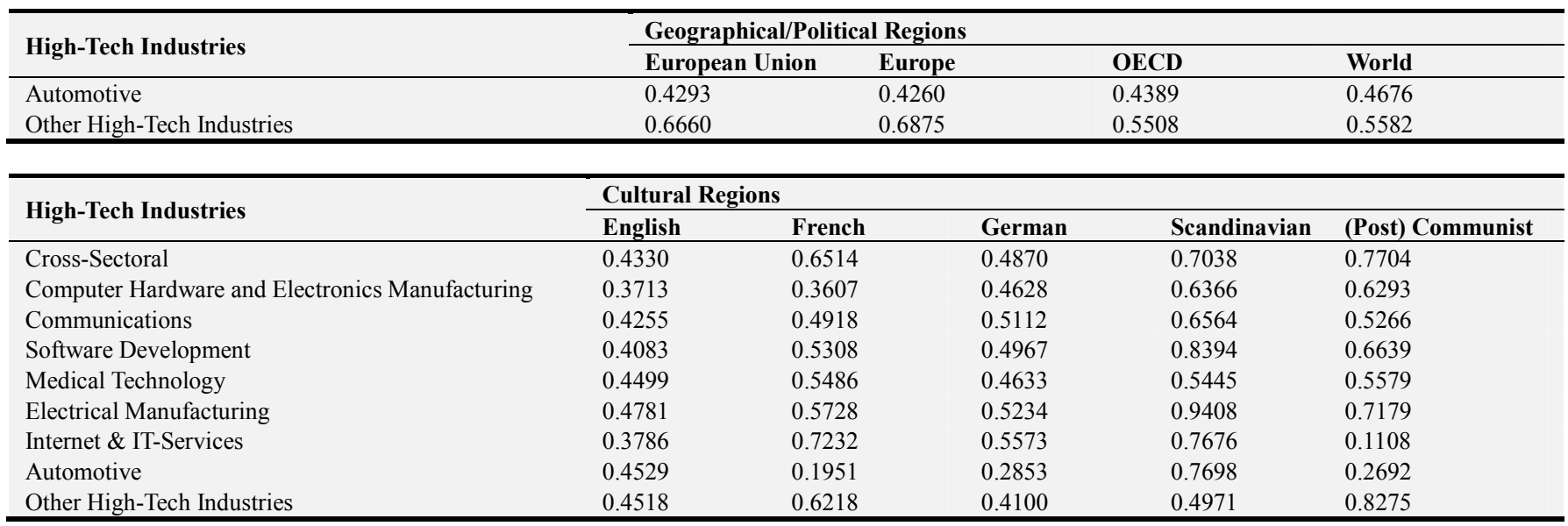

Panel C: Performance (test on accuracy) by country high-tech indicator segmentation and peer pool settings

\begin{tabular}{|c|c|c|c|c|}
\hline Country High-Tech Indicator & European Union & Europe & OECD & World \\
\hline Aggregated/Cross-Sectoral & 0.6901 & 0.6752 & 0.6590 & 0.6451 \\
\hline \multicolumn{5}{|l|}{ R\&D\%GDP } \\
\hline Quarter 1 & 0.7114 & 0.7443 & 0.6787 & 0.4938 \\
\hline Quarter 2 & 0.5557 & 0.5120 & 0.4795 & 0.5623 \\
\hline Quarter 3 & 0.4837 & 0.5535 & 0.5617 & 0.4895 \\
\hline Quarter 4 & 0.7281 & 0.6972 & 0.4938 & 0.6620 \\
\hline \multicolumn{5}{|l|}{ LFPA } \\
\hline Quarter 1 & 0.6367 & 0.6362 & 0.4002 & 0.4062 \\
\hline Quarter 2 & 0.6986 & 0.6998 & 0.4062 & 0.5082 \\
\hline Quarter 3 & 0.5070 & 0.5165 & 0.6672 & 0.6684 \\
\hline Quarter 4 & 0.7557 & 0.7843 & 0.6543 & 0.6466 \\
\hline \multicolumn{5}{|l|}{ TE\%GDP } \\
\hline Quarter 1 & 0.6243 & 0.5212 & 0.4815 & 0.4764 \\
\hline Quarter 2 & 0.6891 & 0.6488 & 0.6137 & 0.6354 \\
\hline Quarter 3 & 0.5781 & 0.5830 & 0.5950 & 0.6306 \\
\hline Quarter 4 & 0.7227 & 0.7193 & 0.5637 & 0.5448 \\
\hline \multicolumn{5}{|l|}{ TE\%TME } \\
\hline Quarter 1 & 0.5016 & 0.5133 & 0.4028 & 0.4368 \\
\hline Quarter 2 & 0.6557 & 0.6480 & 0.4473 & 0.4850 \\
\hline Quarter 3 & 0.6386 & 0.6513 & 0.6677 & 0.6653 \\
\hline Quarter 4 & 0.7369 & 0.7260 & 0.6140 & 0.5928 \\
\hline \multicolumn{5}{|l|}{ High-Tech Index (quarters) } \\
\hline Quarter 1 & 0.7260 & 0.6931 & 0.4002 & 0.4073 \\
\hline Quarter 2 & 0.5286 & 0.5286 & 0.5268 & 0.5936 \\
\hline Quarter 3 & 0.5779 & 0.6145 & 0.6493 & 0.5063 \\
\hline Quarter 4 & 0.7292 & 0.7593 & 0.6189 & 0.6644 \\
\hline \multicolumn{5}{|l|}{ High-Tech Index (clustered) } \\
\hline Cluster 1 & 0.6838 & 0.6395 & 0.4062 & 0.4003 \\
\hline Cluster 2 & 0.6170 & 0.6470 & 0.5897 & 0.4546 \\
\hline Cluster 3 & 0.6625 & 0.6324 & 0.5241 & 0.6017 \\
\hline Cluster 4 & 0.7312 & 0.7411 & 0.7223 & 0.7135 \\
\hline
\end{tabular}

EPV indicates enterprise value, EQV indicates equity value. Panel A reports the results on the performance (accuracy) by multiples. Panel B reports the results on the performance (accuracy) by high-tech sector segmentation. Panel $\mathrm{C}$ reports the results on the performance (accuracy) by country high-tech indicator segmentation. For all panels, both, the synthetic peer group multiple and the relative log-scaled absolute valuation error, are aggregated employing the median.

The results reported in tables 6 and 7 indicate previous findings to be strongly robust, i. e., they are insensitive to both, the valuation error employed and the size of the peer group. Concerning the accuracy of multiples (as reported in the respective panels $\mathrm{A}$ ), the enterprise value to total assets multiple again dominates across all peer pool settings, followed by the equity value multiple (except for some cultural peer pools) and, the multiples show a general tendency to improve with peer pool size (as indicated for the geographical/political peer pools). Sectoral multiples (as reported in the respective panels B) again outperform the cross-sectoral multiple in the geographical/political peer pools in most sectors as well as across the cultural peer pools, although indicating a somewhat weaker superiority, and, the sectoral multiples similarly do not show a clear improvement with an increase in the size of the peer pool. Finally, country high-tech segmented multiples (as reported in the respective 
panels C) again (unsystematically) outperform the aggregated multiple, show no material improvement over sectoral multiples across all peer pools and, the size of the peer pool has no material impact on the performance of the country high-tech indicator segmented multiples (but with a weak tendency to improve for the larger peer pools).

\section{Conclusion}

Empirical evidence on the performance of multiples reveals contradictory results that may be attributed to varying peer pool settings. Inconsistencies have been documented on (i) the performance of enterprise value as opposed to equity value multiples, (ii) the relative superiority of multiples according to the value driver employed and, (iii) the relative superiority of cross-sectoral multiples. Furthermore, the results reveal different peer pools to generate minimum errors on multiple's estimates across countries.

In this study, I examine the systematic impact of peer pooling on (i) the relative superiority of cross-sectoral multiples, (ii) the absolute superiority of sectoral multiples and, (iii) the absolute superiority of cross-sectoral multiples being segmented by various country high-tech indicators. Data on private market transactions is collected from 2000 until 2018, categorized into peer pools formed according to geographical/political criteria as well as according to cultural regions. The final sample population is 22,967 observations on private market transactions. The results allow for some general conclusions and recommendations. First, contradictory results in prior research on multiple's bias may be strongly attributed to the varying peer pools employed. Second, the enterprise value to total assets multiple clearly dominates across all peer pools on a cross-sectoral basis, indicating that contradictory results on multiple's accuracy may not be attributed to the varying peer pools employed (but to other sample characteristics). Third, the performance of sectoral multiples depends on the value driver employed, since they show only a weak relationship with the peer pool setting. Therefore, valuation analysts are recommended (i) to employ larger peer pools when employing cross-sectoral multiples (sectoral as well as country-specific high-tech indicator segmented multiples do not allow for this recommendation), (ii) to employ the enterprise value to total assets multiple valuing private high-tech firms, (iii) to further break down the high-tech sector into sub-sectors and, (iv) to employ sectoral multiples or country high-tech indicator segmented multiples alternately. All results are proved to be strongly robust.

The results of this study are restricted to a variety of limitations. First, following the main body of related research, all transactions of firms with negative earnings fundamentals remained disregarded, thus reducing the initial sample by about 30 percent (unreported). Including these firms might change the results considerably. Second, the sample is systematically modified according to value driver characteristics. As with all sample modifications, the information lost might again modify the results. Finally, the data provided is limited because (i) not all transactions occurring are recorded in the database employed (since there is no official obligation to register) and (ii) the recorded data is often inchoate and sometimes unreliable. Therefore, an increased data availability and reliability would allow for a more comprehensive analysis.

\section{Appendix}

Table 8. Controlling variables employed.

\begin{tabular}{|c|c|}
\hline Category/Variables & Definition of variable/ Explanation and related literature \\
\hline \multicolumn{2}{|l|}{ Deal characteristics: } \\
\hline Negotiation success & $\begin{array}{l}\text { Dummy causal factor vector according to magnitude of multiple in corresponding year (positive = highest quartile, } \\
\text { neutral = quartiles } 2 \text { and } 3 \text {, negative = lowest quartile). } \\
\text { Methodology lends support to the bargaining power hypothesis suggesting that closely controlled firms may have } \\
\text { significant bargaining strength, allowing the owners to receive premia exceeding acquirer's potential gains [74]. }\end{array}$ \\
\hline \multicolumn{2}{|c|}{ Private market transaction (acquisition) characteristics: } \\
\hline & $\begin{array}{l}\text { Dummy causal factor on acquirer being a financial investor or not (based on NACE Rev. } 2 \text { industry affiliation, } 0= \\
\text { non-strategic (financial) buyer }=\text { two-digit codes } 64 \text { to } 66 \text { (banking and financing), } 1=\text { otherwise }=\text { strategic buyer). }\end{array}$ \\
\hline Synergy & $\begin{array}{l}\text { An acquirer other than a financial investor may experience advantages through synergy from the private market } \\
\text { transaction, causing the transaction price to include the value of the acquirer's individual expected synergies. } \\
\text { Methodology is employed e. g. by [75-81]. }\end{array}$ \\
\hline Control & $\begin{array}{l}\text { Dummy causal factor on private market transaction being a majority (control) share acquisition or a minority share } \\
\text { acquisition }(1=\text { majority share transaction }=\text { transaction resulting in a stake above } 50 \text { percent for the acquiror (no matter } \\
\text { whether the acquirer already held a minority share prior to the transaction or not), } 0=\text { minority share transaction = } \\
\text { transaction resulting in a stake below } 50 \text { percent for the acquiror (no matter whether the acquirer already held a minority } \\
\text { share prior to the transaction or not)). } \\
\text { Control shares provide control benefits and control flexibility [82-84]. }\end{array}$ \\
\hline Diversification & $\begin{array}{l}\text { Dummy causal factor on target company being engaged in one or more industries according to predefined high-tech } \\
\text { industry groupings as well as two-digit NACE Rev. } 2 \text { industry breakdown ( } 1=\text { diversified company = engaged in two or } \\
\text { more industries, } 0=\text { pure play = otherwise). } \\
\text { Diversified companies are valued lower than undiversified companies according to excess value and Tobin's q studies } \\
\text { [85-96] and event studies [97-101]. } \\
\text { Methodology is employed e. g. by [64, 102-104]. }\end{array}$ \\
\hline Region of private market & Dummy causal factor on region of transaction, as indicated by the country codes of acquirer and target firm $(1=$ \\
\hline
\end{tabular}




\begin{tabular}{l} 
Category/Variables \\
\hline transaction (acquisition) \\
Method of payment \\
Market (for corporate takeovers) cha \\
Firm characteristics - Profitability: \\
Market condition, market activity
\end{tabular}

Return on sales target firm

Return on assets target firm

Firm characteristics - Risk:

Size of target firm

Business risk

Legal form of acquirer

Legal form of target firm

Absolute size of private market transaction (acquisition) Relative size of private market transaction (acquisition)

Size ratio target to acquirer

Size ratio of private market transaction (acquisition) to acquirer

Firm characteristics - Growth:

Compound annual growth rate of target firm

\section{Definition of variable/ Explanation and related literature}

cross-border transaction, $0=$ domestic transaction).

Methodology is employed e. g. by $[105,106]$.

Dummy causal factor $(1=$ payment made in cash or liabilities, $0=$ otherwise $)$

Methodology lends support to the information asymmetry hypothesis (shareholders of listed targets have no strong incentive to examine the potential acquirer closely, whereas the concentrated ownership of private firms provides their owners with powerful incentives especially when they are paid in stocks) and the corporate monitoring hypothesis (suggesting agency costs to be lower if some investors actively monitor managerial activities) [74].

Method of payment is concluded to be a powerful controlling variable in different settings: Transaction prices are significantly lower when buyers pay in cash providing immediate liquidity to the seller [107]; method of payment is significantly positively related to bidder returns [79]; wealth effects to targets and bidders are higher with cash versus stock deals [108-112]; share-bidders experience a significant negative abnormal return relative to cash-bidders [113, 114]; the signalling implications of the method of payment are likely to differ across bids for private and public targets [115-117]; bidders pay higher premia in more concentrated industries when payment is made with stocks [62]; investigating the relationship between the method of payment in acquisitions, earnings management and operating performance of the buyer [118]; investigating differences in acquisitions occurring during booming and depressed markets [119]; examining the relationship between the premium paid in acquisitions and deal size [104]. acteristics:

Vector of year dummies over sample period 2000 until $2019(1=$ transaction occurred in a given year, $0=$ otherwise $)$ Methodology lends support to the managerial herding hypothesis [119]. It is employed e. g. examining the relation between the premium paid in acquisitions and deal size [104, 120]; examining valuation differences in the boom and crash market periods relative to stable periods of IPOs [121, 122]; comparing the effectiveness of various industry classification codes $[30,62]$

EBT divided by operating sales of fiscal year preceding the private market transaction.

Variable is employed e. g. examining the performance of various industry groupings [33]; examining the performance of industry-related as compared to cross-sectoral multiples [70]; elaborating upon accuracy and drivers' evidence of multiples [5]; examining sell-side analyst's choice on peers [123]. Sometimes EBT is replaced by EBIT [124, 125]. EBIT divided by total assets of fiscal year preceding the private market transaction.

Variable is employed e. g. examining optimal peer selection formulae [66]; examining CEO compensation [126-128] as well as by $[30,33,64]$.

Natural logarithm of (indexed) annual operating sales of fiscal year preceding the private market transaction. Size of the target firm was concluded to be a relevant selection criterion $[129,130]$. Variable is employed e. g. examining optimal peer group definition estimating betas of private firms [60]; examining shifts in the explanatory power of fundamentals in the valuation of IPOs in the new economy period [132]; examining CEO compensation [126, 127] as well as by [123, 131-133].

Sometimes alternative size measures such as ordinary sales or the natural logarithm of assets and market capitalization are employed [5, 30, 31, 59, 67, 70, 104, 125, 134-137].

Dummy causal factor with business risk being proxied by the developmental stage of the private firm, represented by a date of incorporation within five years prior to the private market transaction $(1=$ date of incorporation within five years, $0=$ otherwise).

Methodology is employed e. g. by $[30,105,130]$.

Dummy causal factor on whether the owners of the acquirer may be held responsible for firm debt or not $(1=$ public limited company (unlisted) or joint stock company (unlisted) $=$ no responsibility for debt, $0=$ otherwise $=$ responsibility for debt).

Dummy causal factor on whether the owners of the acquirer may be held responsible for debt of target firm purchased or not, or the prior owners of the target firm retain being held responsible for its debt $(1=$ public limited company (unlisted) or joint stock company (unlisted) $=$ no responsibility for debt, $0=$ otherwise $=$ responsibility for debt).

Variable is employed e. g. examining differences in returns for acquirers of public versus private firms [117].

Natural logarithm of deal value.

Variable is employed e. g. by [104].

Percentage of acquired share of equity.

Variable is employed e. g. by [119].

Natural logarithm of operating sales of target to natural logarithm of operating sales of acquirer, both of fiscal year preceding the private market transaction.

Variable is employed e. g. investigating the returns to shareholders of firms making multiple acquisitions [116]; examining the dependence of the acquirer gains on the relative size of the takeover partners [74]; investigating the short-term market response associated with the announcement of large domestic mergers and acquisitions [79] as well as by $[104,108,131,132,138]$.

Natural logarithm of deal value to natural logarithm of operating sales of acquirer of fiscal year preceding the private market transaction.

Variable is employed e. g. by [104, 108, 138, 139].

Compound five-years annual growth rate of (indexed) operating sales preceding the private market transaction.

Methodology is employed e. g. by [132] as well as with varying durations investigating the effect of R\&D investments on the market value of firms [140], investigating the short-term market response associated with the announcement of large domestic mergers and acquisitions [79], elaborating upon accuracy and drivers' evidence of multiples [5] and, 


\begin{tabular}{ll}
\hline Category/Variables & Definition of variable/ Explanation and related literature \\
\hline & $\begin{array}{l}\text { examining the impact of valuation model choice on target price accuracy [135]. } \\
\text { Firm characteristics - Other: }\end{array}$ \\
$\begin{array}{l}\text { Variable is employed e. g. by [27, 60, 66, 123, 137]. } \\
\text { Type of accounting }\end{array}$ & $\begin{array}{l}\text { Dummy causal factor on type of accounting }(1=\text { consolidated financial statement, } 0=\text { otherwise }) . \\
\text { Variable is related to the finding that earnings quality of private firms depends on the type of accounting [141]. } \\
\text { Variable is employed e. g. by [119]. }\end{array}$ \\
\hline
\end{tabular}

Table 8 categorizes the 19 variables employed to select peers, defines them, gives methodological explanations and, reports related literature. Literature not already included in the reference list is additionally reported.

Table 9. Country classification according to high-tech indicators.

\begin{tabular}{|c|c|c|c|c|c|c|c|c|c|c|c|c|c|c|c|c|c|c|c|c|}
\hline \multirow[t]{2}{*}{ Country } & \multicolumn{4}{|c|}{$\begin{array}{l}\text { Research \& } \\
\text { Development } \\
\text { Expenditure in \% of } \\
\text { GDP }\end{array}$} & \multicolumn{4}{|c|}{$\begin{array}{l}\text { Labor Force per } \\
\text { Patent Application }\end{array}$} & \multicolumn{4}{|c|}{$\begin{array}{l}\text { Technology Exports } \\
\text { in \% of GDP }\end{array}$} & \multicolumn{4}{|c|}{$\begin{array}{l}\text { Technology Exports } \\
\text { in \% of Total } \\
\text { Manufactured Exports }\end{array}$} & \multicolumn{4}{|c|}{ High-Tech Index } \\
\hline & EU & $\mathbf{E}$ & $\mathbf{O}$ & W & EU & $\mathbf{E}$ & $\mathbf{O}$ & W & $\mathbf{E U}$ & $\mathbf{E}$ & $\mathbf{O}$ & W & EU & $\mathbf{E}$ & $\mathbf{O}$ & W & EU & $\mathbf{E}$ & $\mathbf{O}$ & W \\
\hline Argentina & & & & 4 & & & & 4 & & & & 4 & & & & 4 & & & & $4(4)$ \\
\hline Australia & & & 3 & 3 & & & 2 & 2 & & & 4 & 4 & & & 4 & 4 & & & $4(3)$ & $3(3)$ \\
\hline Austria & 2 & 2 & 3 & 2 & 2 & 2 & 3 & 3 & 2 & 2 & 2 & 2 & 3 & 3 & 4 & 4 & $3(2)$ & $3(2)$ & $3(3)$ & $3(3)$ \\
\hline Belgium & 2 & 2 & 3 & 3 & 4 & 4 & 4 & 4 & 1 & 1 & 2 & 2 & 3 & 3 & 4 & 4 & $3(2)$ & $3(2)$ & $4(3)$ & $4(4)$ \\
\hline $\begin{array}{l}\text { Bosnia and } \\
\text { Herzegovina }\end{array}$ & & 4 & & 4 & & 4 & & 4 & & 4 & & 4 & & 4 & & 4 & & $4(4)$ & & $4(4)$ \\
\hline Brazil & & & & 4 & & & & 4 & & & & 4 & & & & 4 & & & & $4(4)$ \\
\hline Bulgaria & 4 & 4 & & 4 & 4 & 4 & & 4 & 3 & 3 & & 3 & 4 & 4 & & 4 & $4(4)$ & $4(4)$ & & $4(4)$ \\
\hline Canada & & & 3 & 3 & & & 2 & 2 & & & 3 & 3 & & & 4 & 4 & & & $4(3)$ & $3(3)$ \\
\hline Chile & & & 4 & 4 & & & 4 & 4 & & & 4 & 4 & & & 4 & 4 & & & $4(4)$ & $4(4)$ \\
\hline China & & & & 4 & & & & 4 & & & & 1 & & & & 1 & & & & $2(3)$ \\
\hline Colombia & & & & 4 & & & & 4 & & & & 4 & & & & 4 & & & & $4(4)$ \\
\hline Croatia & 4 & 4 & & 4 & 4 & 4 & & 4 & 4 & 4 & & 3 & 4 & 3 & & 4 & $4(4)$ & $4(4)$ & & $4(4)$ \\
\hline Cyprus & 4 & 4 & & 4 & 4 & 4 & & 4 & 4 & 4 & & 4 & 2 & 2 & & 3 & $4(4)$ & $4(4)$ & & $4(4)$ \\
\hline Czech Republic & 4 & 3 & 4 & 4 & 4 & 4 & 4 & 4 & 1 & 1 & 1 & 1 & 2 & 2 & 3 & 3 & $3(2)$ & $3(2)$ & $2(2)$ & $4(4)$ \\
\hline Denmark & 1 & 1 & 2 & 2 & 2 & 2 & 3 & 3 & 3 & 3 & 3 & 3 & 3 & 3 & 4 & 3 & $3(2)$ & $3(2)$ & $3(3)$ & $3(3)$ \\
\hline Egypt & & & & 4 & & & & 4 & & & & 4 & & & & 4 & & & & $4(4)$ \\
\hline Estonia & 4 & 3 & 4 & 4 & 4 & 4 & 4 & 4 & 1 & 1 & 1 & 1 & 2 & 2 & 3 & 3 & $3(3)$ & $3(2)$ & $3(3)$ & $4(4)$ \\
\hline Finland & 1 & 1 & 1 & 1 & 2 & 2 & 3 & 3 & 3 & 3 & 3 & 3 & 3 & 3 & 4 & 4 & $2(2)$ & $2(1)$ & $3(3)$ & $2(3)$ \\
\hline France & 2 & 2 & 3 & 3 & 2 & 2 & 3 & 3 & 2 & 2 & 3 & 2 & 1 & 1 & 2 & 2 & $2(2)$ & $2(2)$ & $3(2)$ & $3(3)$ \\
\hline Germany & 1 & 1 & 2 & 2 & 1 & 1 & 3 & 2 & 1 & 2 & 2 & 2 & 3 & 3 & 3 & 3 & $1(1)$ & $1(1)$ & $3(2)$ & $2(3)$ \\
\hline Greece & 4 & 4 & 4 & 4 & 4 & 4 & 4 & 4 & 4 & 4 & 4 & 4 & 3 & 3 & 4 & 4 & $4(4)$ & $4(4)$ & $4(4)$ & $4(4)$ \\
\hline Hong Kong & & & & 4 & & & & 2 & & & & 4 & & & & 3 & & & & $3(3)$ \\
\hline Hungary & 4 & 4 & 4 & 4 & 4 & 4 & 4 & 4 & 1 & 1 & 1 & 1 & 2 & 2 & 3 & 3 & $1(2)$ & $1(1)$ & $2(2)$ & $4(3)$ \\
\hline Iceland & & 2 & 3 & 2 & & 3 & 4 & 3 & & 4 & 4 & 3 & & 1 & 1 & 1 & & $3(2)$ & $3(2)$ & $2(3)$ \\
\hline India & & & & 4 & & & & 4 & & & & 4 & & & & 4 & & & & $4(4)$ \\
\hline Indonesia & & & & 4 & & & & 4 & & & & 4 & & & & 4 & & & & $4(4)$ \\
\hline Ireland & 4 & 3 & 4 & 4 & 4 & 4 & 4 & 4 & 1 & 1 & 1 & 1 & 1 & 1 & 1 & 1 & $3(2)$ & $3(2)$ & $2(2)$ & $3(3)$ \\
\hline Israel & & & 1 & 1 & & & 3 & 2 & & & 2 & 2 & & & 3 & 3 & & & $2(2)$ & $2(2)$ \\
\hline Italy & 4 & 4 & 4 & 4 & 3 & 3 & 4 & 3 & 4 & 4 & 4 & 3 & 4 & 4 & 4 & 4 & $4(4)$ & $4(3)$ & $4(4)$ & $4(4)$ \\
\hline Japan & & & 2 & 2 & & & 2 & 1 & & & 3 & 3 & & & 3 & 3 & & & $2(1)$ & $1(2)$ \\
\hline Jordan & & & & 4 & & & & 4 & & & & 4 & & & & 4 & & & & $4(4)$ \\
\hline Kenya & & & & 4 & & & & 4 & & & & 4 & & & & 4 & & & & $4(4)$ \\
\hline Luxembourg & 4 & 3 & 4 & 4 & 3 & 3 & 4 & 3 & 4 & 4 & 3 & 3 & 4 & 4 & 4 & 4 & $3(3)$ & $3(3)$ & $4(4)$ & $4(4)$ \\
\hline Malaysia & & & & 4 & & & & 3 & & & & 1 & & & & 1 & & & & $2(3)$ \\
\hline Malta & 4 & 4 & & 4 & 4 & 4 & & 4 & 1 & 1 & & 1 & 1 & 1 & & 1 & $1(1)$ & $1(1)$ & & $3(3)$ \\
\hline Montenegro & & 4 & & 4 & & 4 & & 4 & & 4 & & 4 & & 3 & & 4 & & $4(4)$ & & $4(4)$ \\
\hline Netherlands & 3 & 3 & 3 & 3 & 3 & 3 & 4 & 4 & 1 & 1 & 2 & 2 & 1 & 1 & 2 & 2 & $2(2)$ & $2(1)$ & $2(2)$ & $3(3)$ \\
\hline New Zealand & & & 4 & 4 & & & 2 & 2 & & & 4 & 4 & & & 4 & 4 & & & $4(3)$ & $4(3)$ \\
\hline $\begin{array}{l}\text { North } \\
\text { Macedonia }\end{array}$ & & 4 & & 4 & & 4 & & 4 & & 4 & & 4 & & 4 & & 4 & & $4(4)$ & & $4(4)$ \\
\hline Norway & & 3 & 4 & 3 & & 1 & 3 & 2 & & 4 & 4 & 4 & & 2 & 3 & 3 & & $3(2)$ & $4(3)$ & $3(3)$ \\
\hline Pakistan & & & & 4 & & & & 4 & & & & 4 & & & & 4 & & & & $4(4)$ \\
\hline Philippines & & & & 4 & & & & 4 & & & & 1 & & & & 1 & & & & $2(3)$ \\
\hline Poland & 4 & 4 & 4 & 4 & 4 & 4 & 4 & 4 & 3 & 3 & 3 & 3 & 4 & 4 & 4 & 4 & $4(4)$ & $4(4)$ & $4(4)$ & $4(4)$ \\
\hline Portugal & 4 & 4 & 4 & 4 & 4 & 4 & 4 & 4 & 4 & 4 & 4 & 4 & 4 & 4 & 4 & 4 & $4(4)$ & $4(4)$ & $4(4)$ & $4(4)$ \\
\hline Romania & 4 & 4 & & 4 & 4 & 4 & & 4 & 3 & 3 & & 3 & 4 & 4 & & 4 & $4(4)$ & $4(4)$ & & $4(4)$ \\
\hline Russia & & 4 & & 4 & & 2 & & 3 & & 4 & & 4 & & 4 & & 4 & & $3(3)$ & & $4(4)$ \\
\hline Serbia & & 4 & & 4 & & 4 & & 4 & & 4 & & 4 & & 4 & & 4 & & $4(4)$ & & $4(4)$ \\
\hline Singapore & & & & 3 & & & & 2 & & & & 1 & & & & 1 & & & & $1(1)$ \\
\hline Slovak & 4 & 4 & 4 & 4 & 4 & 4 & 4 & 4 & 1 & 1 & 2 & 2 & 4 & 4 & 4 & 4 & $3(4)$ & $3(3)$ & $4(4)$ & $4(4)$ \\
\hline
\end{tabular}




\begin{tabular}{|c|c|c|c|c|c|c|c|c|c|c|c|c|c|c|c|c|c|c|c|c|}
\hline \multirow[t]{2}{*}{ Country } & \multicolumn{4}{|c|}{$\begin{array}{l}\text { Research \& } \\
\text { Development } \\
\text { Expenditure in \% of } \\
\text { GDP }\end{array}$} & \multicolumn{4}{|c|}{$\begin{array}{l}\text { Labor Force per } \\
\text { Patent Application }\end{array}$} & \multicolumn{4}{|c|}{$\begin{array}{l}\text { Technology Exports } \\
\text { in \% of GDP }\end{array}$} & \multicolumn{4}{|c|}{$\begin{array}{l}\text { Technology Exports } \\
\text { in \% of Total } \\
\text { Manufactured Exports }\end{array}$} & \multicolumn{4}{|c|}{ High-Tech Index } \\
\hline & $\mathbf{E U}$ & $\mathbf{E}$ & $\mathbf{O}$ & $\mathbf{W}$ & EU & $\mathbf{E}$ & $\mathbf{O}$ & $\mathbf{W}$ & EU & $\mathbf{E}$ & $\mathbf{O}$ & $\mathbf{W}$ & EU & $\mathbf{E}$ & $\mathbf{O}$ & $\mathbf{W}$ & $\mathbf{E U}$ & $\mathbf{E}$ & $\mathbf{O}$ & $\mathbf{W}$ \\
\hline \multicolumn{21}{|l|}{ Republic } \\
\hline Slovenia & 2 & 2 & 3 & 3 & 3 & 3 & 4 & 4 & 3 & 3 & 3 & 3 & 4 & 4 & 4 & 4 & $3(3)$ & $3(3)$ & $4(3)$ & $4(4)$ \\
\hline South Africa & & & & 4 & & & & 4 & & & & 4 & & & & 4 & & & & $4(4)$ \\
\hline Spain & 4 & 4 & 4 & 4 & 4 & 4 & 4 & 4 & 4 & 4 & 4 & 4 & 4 & 4 & 4 & 4 & $4(4)$ & $4(4)$ & $4(4)$ & $4(4)$ \\
\hline Sri Lanka & & & & 4 & & & & 4 & & & & 4 & & & & 4 & & & & $4(4)$ \\
\hline Sweden & 1 & 1 & 1 & 1 & 2 & 2 & 4 & 3 & 2 & 2 & 2 & 2 & 2 & 2 & 3 & 3 & $1(1)$ & $1(1)$ & $2(2)$ & $2(3)$ \\
\hline Switzerland & & 1 & 2 & 2 & & 3 & 4 & 3 & & 1 & 2 & 2 & & 2 & 2 & 2 & & $1(1)$ & $2(2)$ & $2(3)$ \\
\hline Taiwan & & & & - & & & & 4 & & & & 4 & & & & 4 & & & & - \\
\hline Thailand & & & & 4 & & & & 4 & & & & 1 & & & & 2 & & & & $4(4)$ \\
\hline Turkey & & 4 & 4 & 4 & & 4 & 4 & 4 & & 4 & 4 & 4 & & 4 & 4 & 4 & & $4(4)$ & $4(4)$ & $4(4)$ \\
\hline $\begin{array}{l}\text { United } \\
\text { Kingdom }\end{array}$ & 3 & 3 & 4 & 4 & 1 & 1 & 3 & 3 & 3 & 3 & 3 & 3 & 2 & 2 & 3 & 3 & $3(2)$ & $3(2)$ & $3(3)$ & $4(3)$ \\
\hline United States & & & 2 & 2 & & & 2 & 2 & & & 4 & 4 & & & 2 & 2 & & & $2(2)$ & $2(3)$ \\
\hline
\end{tabular}

GDP indicates Gross Domestic Product, EU indicates European Union member countries, E indicates Europe, O indicates OECD counties and, W indicates World (total sample). A value in the respective column indicates a country's affiliation to the respective peer pool. For the first, third and, fourth indicator, a value of 1 indicates affiliation to quarter 1 (highest) and a value of 4 indicates affiliation to quarter 4 (lowest). For the second indicator, quarters are sorted in inverse order, thus a value of 1 (quarter 1) capturing the countries with the lowest and a value of 4 (quarter 4) capturing the countries with the highest indicators. For the high-tech index, values on quarters are reported without brackets, values on clusters in brackets (both sorted in descending order).

\section{References}

[1] Lie E. and H. J. Lie (2002). Multiples used to Estimate Corporate Value. Financial Analysts Journal 58 (2): 44-54.

[2] Deng M., Easton P. D., and J. Yeo (2012). Another Look at Enterprise and Equity Valuation Based on Multiples. Working Paper.

[3] Nel S. W. (2009). The use of multiples in the South African equity market: is the popularity of the price earnings ratio justifiable from a sector perspective? Meditari Accountancy Research 17 (2): 101-115.

[4] Nel S. W., Bruwer W., and N. Le Roux (2013). Equity- and Entity-Based Multiples in Emerging Markets: Evidence from the JSE Securities Exchange. Journal of Applied Business Research 29 (3): 829-851.

[5] Harbula P. (2009). Valuation Multiples: Accuracy and Drivers Evidence from the European Stock Market. Business Valuation Review 24 (4): 186-200.

[6] Herrmann V. and F. Richter (2003). Pricing with Performance-Controlled Multiples. Schmalenbach Business Review 55: 194-219.

[7] Schreiner A. and K. Spremann (2007). Multiples and their Valuation Accuracy in European Equity Markets. Working Paper.

[8] Chastenet E. and A. Marion (2015). Valuation Using Industry Multiples: How to Choose the Most Relevant Multiples. Business Valuation Review 34 (4): 173-183.

[9] Bagna E. and E. C. Ramusino (2017). Market Multiples and the Valuation of Cyclical Companies. International Business Research 10 (12): 246-266.

[10] Liu J., Nissim D., and J. Thomas (2007). Is Cash Flow King in Valuations? Financial Analysts Journal 63 (2): 56-65.
[11] LeClair M. S. (1990). Valuing the Closely-Held Corporation: The Validity and Performance of Established Valuation Procedures. Accounting Horizons 4 (3): 31-42.

[12] Beatty R. P., Riffe S. M., and R. Thompson (1999). The Method of Comparables and Tax Court Valuations of Private Firms: An Empirical Investigation. Accounting Horizons 13 (2): 177-199.

[13] Baker M. and R. S. Ruback (1999). Estimating Industry Multiples. Working Paper.

[14] Cheng A. C. S. and R. McNamara (2000). The Valuation Accuracy of the Price-Earnings and Price-Book Benchmark Valuation Methods. Review of Quantitative Finance and Accounting 15 (4): 349-370.

[15] Liu J., Nissim D., and J. Thomas (2002). Equity Valuation Using Multiples. Journal of Accounting Research 40 (1): 135-172.

[16] Cassia L., Paleari S., and S. Vismara (2004). The Valuation of Firms Listed on the Nuovo Mercato: The Peer Comparables Approach. Giudici Giancarlo, Roosemboom Peter (eds.). The Rise and Fall of Europe's New Stock Markets, pp. 113-129.

[17] Chan K. C. and N.-F. Chen (1991). Structural and Return Characteristics of Small and Large Firms. The Journal of Finance 46 (4): 1467-1484.

[18] Xu L., Cai F., and C. K. Leung (2007). The Role of Book Value in High-Tech Valuation. Advances in Competitiveness Research 15 (1\&2): 71-80.

[19] Abukari K., Jog V., and B. J. McConomy (2000). The Role and the Relative Importance of Financial Statements in Equity Valuation. Working Paper.

[20] Fernández P. (2001). Valuation Using Multiples: How Do Analysts Reach Their Conclusions? Working Paper.

[21] Sehgal S. and A. Pandey (2010). Equity Valuation Using Price Multiples: A Comparative Study for BRICKS. Asian Journal of Finance and Accounting 2 (1): 68-91. 
[22] Dittmann I. and C. Weiner (2005). Selecting Comparables for the Valuation of European Firms. Working Paper.

[23] Francis J. and K. Schipper (1999). Have Financial Statements Lost Their Relevance? Journal of Accounting Research 37 (2): 319-353.

[24] Kile C. O. and M. E. Phillips (2009). Using Industry Classification Codes to Sample High-Technology Firms: Analysis and Recommendations. Journal of Accounting, Auditing and Finance 24 (1): 35-58.

[25] Bhorjaj S., Lee C. M. C., and D. K. Oler (2003). What's my line? A comparison of industry classification schemes for capital market research. Journal of Accounting Research 41 (5): $745-774$.

[26] Krishnan J. and E. Press (2003). The North American Industry Classification System and Its Implications for Accounting Research. Contemporary Accounting Research 20 (4): 685-717.

[27] Chan L. K. C., Lakonishok J., and B. Swaminathan (2007). Industry Classification and Return Comovement. Financial Analysts Journal 63 (6): 56-70.

[28] Vermorken M. A. M. (2011). GICS or ICB, how different is similar? Journal of Asset Management 12 (1): 30-44.

[29] Hrazdil K. and R. Zhang (2012). The importance of industry classification in estimating concentration ratios. Economics Letters 114 (2): 224-227.

[30] Hrazdil K. and T. Scott (2013). The role of industry classification in estimating discretionary accruals. Review of Quantitative Finance and Accounting 40: 15-39.

[31] Chung D. Y., Hrazdil K., and K. Trottier (2014). Industry Classification and the Efficiency of Intra-Industry Information Transfers. American Journal of Business 29 (1): 95-111.

[32] Guenther D. A. and A. J. Rosman (1994). Differences between COMPUSTAT and CRSP SIC codes and related effects of research. Journal of Accounting and Economics 18 (1): $115-128$.

[33] Kahle K. M. and R. A. Walkling (1996). The Impact of Industry Classifications on Financial Research. Journal of Financial and Quantitative Analysis 31 (3): 309-335.

[34] Amit R. and J. Livnat (1990). Grouping of Conglomerates by their Segments' Economic Attributes: Towards a More Meaningful Ratio Analysis. Journal of Business Finance \& Accounting 17 (1): 85-100.

[35] Walker J. A. and J. B. Murphy (2001). Implementing the North American Industry Classification System at BLS. Monthly Labor Review 124 (12): 15-21.

[36] Clarke R. N. (1989). SICs as Delineators of Economic Markets. The Journal of Business 62 (1): 17-31.

[37] Fan J. P. H. and L. H. P. Lang (2000). The Measurement of Relatedness: An Application to Corporate Diversification. The Journal of Business 73 (4): 629-660.

[38] Hirschey M., Richardson V. J., and S. Scholz (2001). Value Relevance of Nonfinancial Information: The Case of Patent Data. Review of Quantitative Finance and Accounting 17: 223-235.

[39] Johnson M. F., Kasznik R., and K. K. Nelson (2001). The
Impact of Securities Litigation Reform on the Disclosure of Forward-looking Information by High-Technology Firms. Journal of Accounting Research 39 (2): 297-327.

[40] Billings B. K. and R. M. Morton (2002). The Relation Between SFAS No. 95 Cash Flows from Operations and Credit Risk. Journal of Business, Finance \& Accounting 29 (5-6): 787-805.

[41] Espahbodi H., Espahbodi P., Rezaee Z., and H. Tehranian (2002). Stock Price Reaction and Value Relevance of Recognition versus Disclosure: The Case of Stock-Based Compensation. Journal of Accounting and Economics 33 (3): 343-373.

[42] Chen S., DeFond M. L., and C. W. Park (2002). Voluntary Disclosure of Balance Sheet Information in Quarterly Earnings Announcements. Journal of Accounting and Economics 33 (2): 229-251.

[43] Kwon S. S. (2002). Financial Analysts' Forecast Accuracy and Dispersion: High-Tech versus Low-Tech Stocks. Review of Quantitative Finance and Accounting 19: 65-91.

[44] Kwon S. S. and J. Q. Yin (2006). Executive Compensation, Investment Opportunities, and Earnings Management: High-Tech Firms Versus Low-Tech Firms. Journal of Accounting, Auditing and Finance 21 (2): 119-148.

[45] Core J. E., Guay W. R., and Buskirk V. A. (2003). Market Valuations in the New Economy: An Investigation of What Has Changed. Journal of Accounting and Economics 34 (1-3): 43-67.

[46] Dowdell T. D. and E. Press (2004). The Impact of SEC Scrutiny on Financial Statement Reporting of In-Process Research and Development Expense. Journal of Accounting and Public Policy 23 (3): 227-244.

[47] Bowen R. M., Davis A. K., and D. A. Matsumoto (2005). Emphasis on Pro Forma versus GAAP Earnings in Quarterly Press Releases. Determinants, SEC Interventions, and Market Reactions. The Accounting Review 80 (4): 1011-1038.

[48] Mohd E. (2005). Accounting for Software Development Costs and Information Asymmetry. The Accounting Review 80 (4): 1211-1231.

[49] Klobucnik J. and S. Sievers (2013). Valuing high-technology growth firms. Journal of Business Economics 83: 947-984.

[50] La Porta R., Lopez-de-Silanes F., Shleifer A., and R. W. Vishny (1997). Legal Determinants of External Finance. The Journal of Finance 52 (3): 1131-1150.

[51] Nissim D. (2013). Relative Valuation of U.S. Insurance Companies. Review of Accounting Studies 18: 324-359.

[52] Sommer F., Rose C. and A. Wöhrmann (2014). Negative Value Indicators in Relative Valuation - An Empirical Perspective. Journal of Business Valuation and Economic Loss Analysis 9 (1): 23-54.

[53] Kim M. and J. R. Ritter (1999). Valuing IPO's. Journal of Financial Economics 53 (3): 409-437.

[54] Yoo Y. K. (2006). The valuation accuracy of equity valuation using a combination of multiples. Review of Accounting and Finance 5 (2): 108-123.

[55] Schreiner A. (2007). Equity Valuation Using Multiples: An Empirical Investigation. Gabler. 
[56] Sommer F. and A. Wöhrmann (2011). Triangulating the Accuracy of Comparable Company Valuations: A Multidimensional Analysis Considering Interaction Effects. Working Paper.

[57] Chullen A., Kaltenbrunner H., and B. Schwetzler (2015). Does consistency improve accuracy in multiple-based valuation? Journal of Business Economics 85: 635-662.

[58] Cooper I., and L. Cordeiro (2008). Optimal Equity Valuation Using Multiples: The Number of Comparable Firms. Working Paper.

[59] Bowman R. G., Bush S. R., and L. Y. Graves (2005). Estimating betas using comparable company analysis: Is it a reliable method. Jassa 2005 (1): 10-14, 23.

[60] Bowman R. G. and S. R. Bush (2006). Using Comparable Companies to Estimate the Betas of Private Companies. Journal of Applied Finance 16 (2): 71-81.

[61] Asche F. and B. Misund (2016). Who's a major? A novel approach to peer group selection: Evidence from oil and gas companies. Cogent Economics and Finance 4: 1-12.

[62] Madura J., Ngo T., and A. M. Viale (2012). Why do merger premiums vary across industries and over time? The Quarterly Review of Economics and Finance 52 (1): 49-62.

[63] Hausman J. A. and W. E. Taylor (1981). Panel Data and Unobservable Individual Effects. Econometrica 49 (6): 1377-1398.

[64] Stockdale J. J. (1986). Comparison of Publicly-Held Companies with Closely-Held Business Entities. Business Valuation Review 5 (4): 3-11.

[65] Alford A. W. (1992). The Effect of the set of Comparable Firms on the Accuracy of the Price-Earnings Valuation Method. Journal of Accounting Research 30 (1): 94-108.

[66] Bhojraj S. and C. M. C. Lee (2002). Who is my Peer? A Valuation-Based Approach to the Selection of Comparable Firms. Journal of Accounting Research 40 (2): 407-439.

[67] Codau C. (2013). Influencing Factors of Valuation Multiples of Companies. Annales Universitatis Apulensis Series Oeconomica 15 (2): 391-401.

[68] Sahoo S. and P. Rajib (2013). Comparable firm's P/E multiple and IPO valuation: An empirical investigation for Indian IPOs. Decision 40 (1-2): 27-46.

[69] Hickman K. and G. H. Petry (1990). A Comparison of Stock Price Predictions Using Court Accepted Formulas, Dividend Discount, and $\mathrm{P} / \mathrm{E}$ Models. Journal of the Financial Management Association 19 (2): 76-87.

[70] Henschke S. and C. Homburg (2009). Equity valuation using multiples: Controlling for differences amongst peers. Working Paper.

[71] Kaplan S. N. and R. S. Ruback (1995). The Valuation of Cash Flow Forecasts: An Empirical Analysis. The Journal of Finance 50 (4): 1059-1093.

[72] Gilson S. C., Hotchkiss E. S., and R. S. Ruback (2000). Valuation of Bankrupt Firms. The Review of Financial Studies 13 (1): 43-74.

[73] Dittmann I. and E. Maug (2008). Biases and Error Measures: How to Compare Valuation Methods. Working Paper.
[74] Draper P. and K. Paudyal (2006). Acquisitions: Private versus Public. European Financial Management 12 (1): 57-80.

[75] Eckbo E. B. (1992). Mergers and the Value of Antitrust Deterrence. The Journal of Finance 47 (3): 1005-1029.

[76] Agrawal A., Jaffe J. F., and G. N. Mandelker (1992). The Post - Merger Performance of Acquiring Firms: A Re-Examination of an Anomaly. The Journal of Finance 47 (4): 1605-1621.

[77] Roach G. P. (1998). Control Premiums and Strategic Mergers. Business Valuation Review 17 (4): 42-49.

[78] Hietala P., Kaplan S. N., and D. T. Robinson (2002). What is the Price of Hubris? Using Takeover Battles to Infer Overpayments and Synergies. Working Paper.

[79] Kiymaz H. and K. H. Baker (2008). Short-Term Performance, Industry Effects, and Motives: Evidence from Large M\&As. Quarterly Journal of Finance and Accounting 47 (2): 17-44.

[80] Antoniou A., Arbour P., and H. Zaho (2008). How Much Is Too Much: Are Merger Premiums Too High? European Financial Management 14 (2): 268-287.

[81] Paglia J. K. and M. Harjoto (2010). The Discount for Lack of Marketability in Privately Owned Companies: A Multiples Approach. Journal of Business Valuation and Economic Loss Analysis 5 (1): 1-24.

[82] Jankowske W. (1995). Frameworks for Analysis of Control Premiums. Business Valuation Review 14 (1): 3-10.

[83] Booth R. A. (2001). Minority Discounts and Control Premiums in Appraisal Proceedings. The Business Lawyer 57 (1): 127-161.

[84] Hall L. S. (2014). Determining Control Premiums: A Better Approach. Valuation Strategies 17 (2): 44-46.

[85] Wernerfeldt B. and C. A. Montgomery (1988). Tobin's q and the Importance of Focus in Firm Performance. The American Economic Review 78 (1): 246-250.

[86] Lang L. H. P. and R. M. Stulz (1994). Tobin's q, Corporate Diversification and Firm Performance. Journal of Political Economy 102 (6): 1248-1280.

[87] Berger P. G. and E. Ofek (1995). Diversification's Effect on Firm Value. Journal of Financial Economics 37 (1): 35-65.

[88] Servaes H. (1996). The value of diversification during the conglomerate merger wave. The Journal of Finance 51 (4): 1201-1225.

[89] Denis D. J., Denis D., and A. Sarin (1997). Agency Problems, Equity Ownership and Corporate Diversification. The Journal of Finance 52 (1): 135-160.

[90] Lins K. and H. Servaes (1999). International evidence on the value of corporate diversification. The Journal of Finance 54 (6): 2215-2239.

[91] Klein P. G. (2001). Were the Acquisitive Conglomerates Inefficient? The RAND Journal of Economics 32 (4): 745-761.

[92] Fauver L., Houston J., and A. Naranjo (2002). Capital Market Development, Integration, Legal Systems and the Value of Corporate Diversification: A Cross Country Analysis. Working Paper. 
[93] Denis D. J., Denis D., and K. Yost (2002). Global Diversification, Industrial Diversification and Firm Value. The Journal of Finance 57 (5): 1951-1971.

[94] Billet M. T. and D. C. Mauer (2003). Cross-Subsidies, External Financing Constraints and the Contribution of the Internal Capital Market to Firm Value. Review of Financial Studies 16 (4): 1167-1201.

[95] Best R. W., Hodges C. W., and B.-X. Lin (2004). Does Information Asymmetry Explain the Diversification Discount? Journal of Financial Research 27 (2): 235-249.

[96] Villalonga B. (2004). Does Diversification Cause the Diversification Discount? Financial Management 53 (2): 5-26.

[97] Comment R. and G. A. Jarrell (1995). Corporate focus and stock returns. Journal of Financial Economics 37 (1): 67-87.

[98] Hubbard G. R. and D. Paglia (1999). A Reexamination of the Conglomerate Merger Wave in the 1960s: An Internal Capital Market View. The Journal of Finance 54 (3): 1131-1152.

[99] Lamont O. A. and C. Polk (2002). Does Diversification Destroy Value? Evidence from Industry Shocks. Journal of Financial Economics 63 (1): 51-77.

[100] Hyland D. C. and D. J. Diltz (2002). Why Firms Diversify: An Empirical Examination. Financial Management 31 (1): 51-81.

[101] Burch T. R. and V. K. Nanda (2003). Divisional Diversity and the Conglomerate Discount: The Evidence from Spinoffs. Journal of Financial Economics 70 (1): 69-98.

[102] Dos Santos M. B., Errunza V. R., and D. P. Miller (2008). Does corporate international diversification destroy value? Evidence from cross-border mergers and acquisitions. Journal of Banking and Finance 32 (12): 2716-2724.

[103] Ozbas O. and D. S. Scharfstein (2010). Evidence on the Dark Side of Internal Capital Markets. The Review of Financial Studies 23 (2): 581-599.

[104] Alexandridis G., Fuller K. P., Terhaar L., and N. G. Travlos (2013). Deal size, acquisition premia and shareholder gains. Journal of Corporate Finance 20: 1-13.

[105] Hertzel M. and R. L. Smith (1993). Market Discounts and Shareholder Gains for Placing Equity Privately. The Journal of Finance 48 (2): 459-469.

[106] Dodel K. (2013). Private Firm Valuation and M\&A: Calculating Value and Estimating Discounts in the New Market Environment. Wiley.

[107] Officer M. S. (2007). The price of corporate liquidity: Acquisition discounts for unlisted targets. Journal of Financial Economics 83 (3): 571-598.

[108] Eckbo E. B., Giammarino R. M., and R. L. Heinkel (1990). Asymmetric Information and the Medium of Exchange in Takeovers: Theory and Tests. Review of Financial Studies 3 (4): 651-676.

[109] Berkovitch E. and M. P. Narayanan (1990). Competition and Medium of Exchange in Takeovers. The Review of Financial Studies 3 (2): 153-174.

[110] Harris R. S. and D. Ravenscraft (1991). The Role of Acquisitions in Foreign Direct Investment: Evidence from the U:S. Stock Market. The Journal of Finance 46 (3): 825-844.
[111] Servaes H. (1991). Tobin's Q and the Gains from Takeovers. The Journal of Finance 46 (1): 409-419.

[112] Andrade G., Mitchell M., and E. Stafford (2001). New Evidence and Perspectives on Mergers. Journal of Economic Perspectives 15 (2): 103-120.

[113] Travlos N. G. (1987). Corporate Takeover Bids, Methods of Payment and Bidding Firms' Stock Returns. The Journal of Finance 42 (4): 943-963.

[114] Bellamy D. E. and W. M. Lewin (1992). Corporate Takeovers, Method of Payment, and Bidding Firms' Shareholder Returns: Australian Evidence. Asia Pacific Journal of Management 9 (2): 137-149.

[115] Chang S. (1998). Takeovers of Privately Held Targets, Methods of Payment, and Bidder Returns. The Journal of Finance 53 (2): 773-784.

[116] Fuller K., Netter J., and M. Stegemoller (2002). What Do Returns to Acquiring Firms Tell Us? Evidence from Firms That Make Many Acquisitions. The Journal of Finance 57 (4): 1763-1793.

[117] da Silva Rosa R., Limmack R., Supriadi, and D. Woodliff (2004). The Equity Wealth Effects of Method of Payment in Takeover Bids for Privately Held Firms. Australian Journal of Management 29 (1): 93-110.

[118] Heron R. and E. Lie (2002). Operating Performance and the Method of Payment in Takeovers. Journal of Financial and Quantitative Analysis 37 (1): 137-155.

[119] Bouwman C. H. S., Fuller K., and A. S. Nain (2009). Market Valuation and Acquisition Quality: Empirical Evidence. The Review of Financial Studies 22 (2): 633-679.

[120] Jovanovic B. and P. L. Rousseau (2001). Mergers and Technological Change: 1885-1998. Working Paper.

[121] Bhagat S. and S. Rangan (2003). IPO Valuation in the New and Old Economies. Working Paper.

[122] Aggarwal R., Bhagat S., and S. Rangan (2009). The Impact of Fundamentals on IPO Valuation. Financial Management 38 (2): 253-284.

[123] De Franco G., Hope O.-K., and S. Larocque (2015). Analyst's choice of peer companies. Review of Accounting Studies 20: 82-109.

[124] Roback E. and L. S. Hall (2001). Bringing Sanity to Marketability Discounts: A New Data Source. Valuation Strategies 4 (6): 6-46.

[125] Parvinder A., Kweh Q. L., and M. Deepanker (2018). Performance comparison between domestic and international firms in the high-technology industry. Eurasian Business Review 8: 477-490.

[126] Albuquerque A. M. (2009). Peer firms in relative performance evaluation. Journal of Accounting and Economics 48 (1): 69-89.

[127] Albuquerque A. M., De Franco G., and R. S. Verdi (2013). Peer choice in $\mathrm{CEO}$ compensation. Journal of Financial Economics 108 (1): $160-181$

[128] Dikolli S. S., Hofmann C., and T. Pfeiffer (2013). Relative performance evaluation and peer-performance summarization errors. Review of Accounting Studies 18: 34-65. 
[129] Conrick C. J. (2006). An Analysis of the Relationship of Publicly Traded Stock Multiples to Closely Held Firm Value Multiples. Business Valuation Review 21 (4): 173-181.

[130] Bolten S. E., Brockardt J. W., and M. J. Ward (1987). The Summary (Build-Up) Capitalization Rate Factors for Retailers. Business Valuation Review 6 (1): 6-13.

[131] Silber W. (1991). Discounts on Restricted Stock: The Impact of Illiquidity on Stock Prices. Financial Analysts Journal 47 (4): 60-64.

[132] McConaughy D. L., Cary D., and C. Chen (2000). Factors Affecting Discounts on Restricted Stock. Valuation Strategies 4 (6): 14-20.

[133] Abbott A. B. (2012). Estimating the Discount for Lack of Marketability: A Best fit Model. Valuation Strategies 15 (3): 20-25.

[134] Asness C. S., Porter B. R., and R. L. Stevens (2000). Predicting Stock Returns Using Industry-Relative Firm Characteristics. Working Paper.

[135] Demirakos E. G., Strong N. C., and M. Walker (2010). Does valuation model choice affect target price accuracy? European Accounting Review 19 (1): 1-50.
[136] Cooper E. W., Barenbaum L., and W. Schubert (2013). Using Guideline Company Multiples for Small Firm Valuations. Valuation Strategies 16 (4): 4-17.

[137] Yin Y., Peasnell K., Lubberink M., and H. G. Hunt (2014). Determinants of Analysts' Target P/E Multiples. Journal of Investing 23 (3): 35-42.

[138] Moeller S. B., Schlingemann F. P., and R. M. Stulz (2004). Firm size and the gains from acquisitions. Journal of Financial Economics 73 (2): 201-228.

[139] Asquith P., Bruner R. F., and D. W. Mullins (1983). The gains to bidding firms from merger. Journal of Financial Economics 11 (1-4): 121-139.

[140] Bae S. C. and D. Kim (2003). The Effect of R\&D Investments on Market Value of Firms: Evidence from the U.S., Germany, and Japan. Multinational Business Review 11 (3): 51-75.

[141] Bonacchi M., Marra A., and P. Zarowin (2017). Earnings Quality of Private and Public Firms: Business Groups versus Stand-Alone Firms. Working Paper. 